\title{
Marine versus Continental Sources of lodine and Selenium in Rainfall at Two European High-Altitude Locations
}

\author{
Elke Suess, ${ }^{\dagger \dagger}$ Franziska Aemisegger, ${ }^{\S}$ Jeroen E. Sonke, ${ }^{\| \odot}$ Michael Sprenger, ${ }^{\S}$ Heini Wernli, \\ and Lenny H. E. Winkel ${ }^{*},+,+0$ \\ ${ }^{\dagger}$ Institute of Biogeochemistry and Pollutant Dynamics, ETH Zurich, 8092 Zurich, Switzerland
${ }^{\ddagger}$ Eawag, Swiss Federal Institute of Aquatic Science and Technology, 8600 Duebendorf Switzerland
${ }^{\S}$ Institute for Atmospheric and Climate Science, ETH Zurich, 8092 Zurich, Switzerland
${ }^{\|}$Observatoire Midi-Pyrénées, CNRS-GET, Université de Toulouse, 31400 Toulouse, France
}

Supporting Information

ABSTRACT: The essential elements selenium (Se) and iodine (I) are often present in low levels in terrestrial diets, leading to potential deficiencies. Marine I and Se emissions and subsequent atmospheric wet deposition has been suggested to be an important source of I and Se to soils and terrestrial food chains. However, the contribution of recycled moisture of continental origin to I and Se to precipitation has never been analyzed. Here we report concentrations and speciation of I and Se, as well as of bromine (Br), sulfur (S), and DOC- $\delta^{13} \mathrm{C}$ signatures for weekly collected precipitation samples (in the period of April 2015 to September 2016) at two high altitude sites, i.e., Jungfraujoch (JFJ; Switzerland) and Pic du Midi (PDM; France). Analysis of precipitation

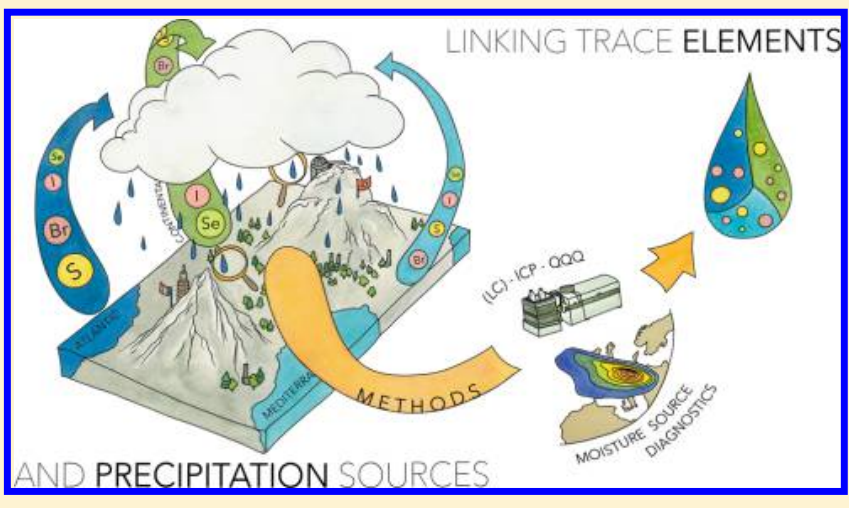
chemistry and moisture sources indicate combined marine and continental sources of precipitation and $\mathrm{Se}, \mathrm{I}, \mathrm{Br}$, and $\mathrm{S}$ at both sites. At JFJ, concentrations of I and Se were highest when continental moisture sources were dominant, indicating important terrestrial sources for these elements. Furthermore, correlations between investigated elements and DOC- $\delta{ }^{13} \mathrm{C}$, particularly when continental moisture source contributions were high, indicate a link between these elements and the source of dissolved organic matter, especially for I (JFJ and PDM) and Se (JFJ).

\section{INTRODUCTION}

Importance of lodine (I) and Selenium (Se) in Human Health. Many trace elements are essential for human health, however, low dietary intake can cause micronutrient deficiencies that have been estimated to affect over 3 billion people around the globe. ${ }^{1}$ Two such essential trace elements, which are often deficient in human diets are iodine (I) and selenium $(\mathrm{Se}){ }^{2,3}$ Iodine plays a crucial role in biochemical processes in the body as it is the main component of thyroid hormones. ${ }^{4}$ Despite the fact that the body requires relatively small amounts of I, deficiency disorders caused by inadequate intakes are widespread. ${ }^{2,5}$ Also, Se is an essential element for humans as it is needed in a small set of selenoproteins that serve redox functions. ${ }^{6-9}$ Sources of both I and Se in the human diet are food crops (especially for Se), meat, dairy products, sea food, and food additives, especially for I in the form of iodized salt. ${ }^{5,10}$

Marine-Derived Precipitation as a Source of I and Se to Terrestrial Environments. Precipitation in air masses with a marine moisture origin has been hypothesized to be an important source of I and Se to terrestrial environments and thus agricultural soils and food crops. ${ }^{5,11}$ Particularly biogenic marine emissions have been suggested as a dominant source of I and Se to the marine atmosphere. ${ }^{5,11-15}$ Marine biogenic I emissions are mainly in the form of methyl iodide $\left(\mathrm{CH}_{3} \mathrm{I}\right)$ and diiodomethane $\left(\mathrm{CH}_{2} \mathrm{I}_{2}\right)$, and for $\mathrm{CH}_{3} \mathrm{I}$ marine emission rates of up $610 \mathrm{Gg} \mathrm{yr}^{-1}$ have been reported. ${ }^{16}$ Also abiotic production of volatile $\mathrm{I}$ species (e.g., $\mathrm{I}_{2}$ ) constitutes an important pathway for marine I emissions. ${ }^{17,18}$ These emitted I compounds photodissociate rapidly in the atmosphere to generate I atoms. Following gas-phase reactions (photolysis and oxidation), iodine oxides are formed ( $\mathrm{IO}, \mathrm{I}_{x} \mathrm{O}_{y}(x=a-b$, $y=a-b)$ and hypoiodous acid: HOI), which are taken up in the aqueous phase. ${ }^{17}$ In the aerosol, various inorganic I species may be present (e.g., $\mathrm{I}^{-}, \mathrm{HOI}, \mathrm{I}_{2}, \mathrm{ICl}, \mathrm{IBr}_{\mathrm{IO}_{3}}^{-}$), however, the IX $(\mathrm{X}=\mathrm{Cl}, \mathrm{Br}, \mathrm{I})$ species are volatile and therefore partition more to the gas-phase than to the liquid-phase. ${ }^{17}$ Hypoiodous

Received: October 1, 2018

Revised: December 18, 2018

Accepted: January 18, 2019

Published: January 18, 2019 
acid reacts with various reductants (e.g., sulfite and DOM) to form $\mathrm{I}^{-19}$ which is together with $\mathrm{IO}_{3}^{-}$the main I species found in rainfall. ${ }^{12,20}$

For Se, fewer studies on volatile emissions are available but, similar to I, a dominant marine biogenic source for Se was suggested for the Southern Hemisphere. ${ }^{21}$ A number of studies have measured volatile Se concentrations and fluxes in marine environments and estuaries. ${ }^{25-29}$ These studies showed that dimethyl selenide (DMSe; $\left[\mathrm{CH}_{3}\right]_{2} \mathrm{Se}$ ) was the main gaseous $\mathrm{Se}$ species, followed by dimethyl selenenyl sulfide (DMSeS; $\left[\mathrm{CH}_{3}\right]_{2} \mathrm{SeS}$ ), and dimethyl diselenide (DMDSe; $\left.\left[\mathrm{CH}_{3}\right]_{2} \mathrm{Se}_{2}\right)$. These volatile Se species undergo photolysis, hydrolysis, and gas-phase reactions with hydroxyl radical, nitrate radical, ozone, and halogen atoms ${ }^{22}$ leading to relatively short estimated lifetimes, i.e., between $5 \mathrm{~min}$ and $\sim 6 \mathrm{~h}^{23}$ Wang and Tang ${ }^{22}$ showed in a theoretical study that the reaction of DMSe and $\mathrm{OH}$ produces dimethylselenoxide (DMSeO), which can be further oxidized to elemental Se and Se oxide (SeO). Theoretical predictions indicate that $\mathrm{SeO}$ can be further oxidized to $\mathrm{SeO}_{2}$, via reaction with $\mathrm{HO}_{2} \cdot{ }^{24} \mathrm{SeO}_{2}$ is water-soluble and forms selenous acid $\left(\mathrm{H}_{2} \mathrm{SeO}_{3}\right)$, which can be further oxidized to selenic acid $\left(\mathrm{H}_{2} \mathrm{SeO}_{4}\right)$.

Marine versus Continental Sources. Although most studies indicate that marine environments are the main source areas of volatile organic I and Se emissions, evidence is increasing that terrestrial environments could also be important emitters of volatile organic I and Se compounds. For example terrestrial sources of $\mathrm{CH}_{3} \mathrm{I}$ have been reported for rice paddies, ${ }^{30,31}$ forests, ${ }^{32}$ salt marshes, and coastal wetlands. ${ }^{33,34}$ A recent study in a pristine wetland in South Switzerland revealed substantial volatile fluxes of Se (max. 120 $\left.\mu \mathrm{g} \mathrm{m}^{-2} \mathrm{~d}^{-1}\right) .^{35}$ Extrapolation of observed fluxes to global wetland areas equals $5-10 \%$ of the currently estimated marine Se volatilization. ${ }^{35}$ Furthermore, in a more holistic approach using airplane measurements over the United States and the North Atlantic as well as data from a long-term groundobserving network ${ }^{36}$ determined a terrestrial flux of $\mathrm{CH}_{3} \mathrm{I}$ around $2.7 \mu \mathrm{g} \mathrm{m}^{-2} \mathrm{~d}^{-1}$, which was found to be largely derived from vegetation and soils. Interestingly, this flux is similar in magnitude to previous estimates of the marine fluxes. ${ }^{36}$ However, it is likely that terrestrial emissions (e.g., from soils, vegetation, wetlands, and surface waters) of I and Se are still largely unknown due to the large heterogeneity of terrestrial environments and the lack of data from these different environments.

Atmospheric Deposition of I and Se. I and Se are deposited to the earth surface via both wet and dry deposition. ${ }^{5,11}$ A number of studies have determined concentrations and speciation of I and Se in wet deposition. For I in rainfall, total concentrations from $7.88 \mathrm{nM}$ for continental rainfall to $39.4 \mathrm{nM}$ for marine rainfall were reported. ${ }^{5}$ Furthermore, Gilfedder et al. ${ }^{20,37}$ measured average I concentrations of $10 \mathrm{nM}, 14 \mathrm{nM}$, and $11 \pm 7 \mathrm{nM}$ in rain samples from the Swiss Alps, the Black Forest, and Lake Constance, respectively, using ICP-MS (inductively coupled plasma mass spectrometry) as well as speciation by IC-ICP-MS (ion chromatography-inductively coupled plasma mass spectrometry). The majority of I was suggested to be organically bound $\mathrm{I}$, followed by iodide $\left(\mathrm{I}^{-}\right)$, and iodate $\left(\mathrm{IO}_{3}{ }^{-}\right) \cdot{ }^{12,20,37}$ There are a number of studies that measured Se concentrations in rainfall at various locations. ${ }^{1,38-52}$ These studies reported concentrations between 0.06 and $32 \mathrm{nM}$, with highest values measured close to industrial sites. Speciation of Se may give information on sources and atmospheric transformations; however, Se speciation in rainwater was only reported in a limited number of papers, e.g., refs 41, 42, 46, 47, 49, 50, 53, and 54. Most of these studies used hydride generation atomic absorption spectrometry (HG-AAS) or hydride generation atomic fluorescence spectrometry (HG-AFS) combined with oxidative or reductive pretreatments of the sample to quantify $\mathrm{Se}(\mathrm{IV})$, the sum of $\mathrm{Se}(\mathrm{IV})$ and $\mathrm{Se}(\mathrm{VI})$, and an operationally defined organic fraction of Se. ${ }^{34,42}$ More recently, Wallschläger \& London ${ }^{54}$ analyzed a suburban rainwater sample using liquid chromatography coupled to HG-ICP-MS technology (IC-HGICP-DRC-MS $)^{54}$ and found selenate $\left(\mathrm{SeO}_{4}{ }^{2-}\right)$ and selenite $\left(\mathrm{SeO}_{3}{ }^{2-}\right)$. Apart from this single rainwater sample, ICP-MS based Se speciation data for rainwater are not available.

Although long-range atmospheric transport of marinederived I and Se has been suggested, ${ }^{14,15,21,41,55-57}$ studies that directly link I and Se in rainfall to the origin of moisture sources are scarce. To study potential long-range transport and contributions of marine versus continental moisture sources, we investigated time series of I and Se concentrations and speciation in wet deposition at two high altitude sites, i.e., Jungfraujoch (Alps, Switzerland) and Pic du Midi (Pyrenees, France). Apart from I and Se, we determined bromine (Br) and sulfur $(S)$ concentrations and speciation. $\mathrm{Br}$ and $\mathrm{S}$ share chemical properties and environmental pathways with I and Se; however, they generally have higher environmental concentrations than I and Se, e.g., about $10^{3}$ times higher in oceans. $^{11,58,59}$ Furthermore, $\mathrm{Br}$ and $\mathrm{S}$ have well-known biogenic marine sources (e.g., bromoform $\left(\mathrm{CHBr}_{3}\right)$ and dimethyl sulfide (DMS)). ${ }^{60}$ Shorter-lived bromo-organic compounds, such as $\mathrm{CHBr}_{3}$, decompose in the troposphere, whereas longer-lived bromo-organic compounds may slowly ascend across the tropopause. ${ }^{61}$ Tropospheric inorganic $\mathrm{Br}$ species are produced from $\mathrm{Br}$ lost from sea salt aerosol (referred to as debromination), photolysis, and oxidation of $\mathrm{CHBr}_{3}$ (by $\mathrm{OH}$ ) and other short-lived bromo-organic compounds. Inorganic $\mathrm{Br}$ cycles between radical $\mathrm{BrO}_{x}$ species $(x=1-3)$ and nonradical reservoirs (e.g., $\mathrm{HOBr}, \mathrm{BrO}_{3}{ }^{-}$, and $\left.\mathrm{BrNO}_{3}\right){ }^{62}$ These species undergo heterogeneous reactions and can finally form $\mathrm{Br}^{-}$in aerosols, ${ }^{62}$ which is the dominant $\mathrm{Br}$ species found in rainfall. ${ }^{37}$ Atmospheric DMS can be oxidized both in the gas- and the aqueous-phase. In the gas-phase, two main reaction pathways occur: addition of an $\mathrm{O}$ atom and abstraction of an $\mathrm{H}$ atom. ${ }^{63}$ The $\mathrm{H}$-abstraction pathway in the gas-phase leads predominantly to $\mathrm{SO}_{2}$, whereas the addition pathway leads to MSA involving multiphase processes. ${ }^{64} \mathrm{Gas}$ phase oxidation is dominated by reactions with $\mathrm{BrO}$, chlorine, and the hydroxyl $(\mathrm{OH})$ radical. ${ }^{64}$ Finally, $\mathrm{SO}_{2}$ is either oxidized in the gas-phase (by reaction with the $\mathrm{OH}$ radical), or it can be taken up by cloud droplets and undergo aqueousphase oxidation. ${ }^{65}$ Aqueous phase oxidation of DMS proceeds mainly via reaction with ozone, yielding DMSO, which is further oxidized to MSIA and MSA by $\mathrm{HO}$ radical and ozone. $^{64}$

Specifically, the objectives of this study were (i) to investigate the concentration and speciation of $\mathrm{I}, \mathrm{Se}, \mathrm{Br}$, and $S$ in relation to continental and marine origin of precipitation and (ii) to get first insights into potential biogenic versus anthropogenic sources of $\mathrm{I}, \mathrm{Se}, \mathrm{Br}$, and S. Furthermore, this study presents the first quantitative and qualitative data on I and $\mathrm{Se}$ in precipitation at high-altitude sites and time series for speciation of $\mathrm{I}, \mathrm{Se}, \mathrm{Br}$, and $\mathrm{S}$ in precipitation. 


\section{MATERIALS AND METHODS}

Rain Water Sampling at Jungfraujoch and Pic du Midi. Precipitation was collected at two high altitude sites, the High Altitude Research Station Jungfraujoch (JFJ) at $3580 \mathrm{~m}$ a.s.l. $\left(46^{\circ} 32^{\prime} 53^{\prime \prime} \mathrm{N} 7^{\circ} 59^{\prime} 2^{\prime \prime} \mathrm{E}\right.$, WGS 84) in the Swiss Alps and at the Pic du Midi (PDM) Observatory $\left(42^{\circ} 56^{\prime} 11^{\prime \prime} \mathrm{N}\right.$ $0^{\circ} 08^{\prime} 34^{\prime \prime}$, WGS 84) at $2877 \mathrm{~m}$ a.s.l. in the French Pyrenees. These sites are particularly suitable to investigate long-range transport as they are often exposed to free tropospheric air. ${ }^{66,67}$ At both sites, bulk precipitation was collected with an open sampler (JFJ bulk/PDM bulk) with a collection area of 0.04 $\mathrm{m}^{2}$. In addition to the bulk sampler at PDM, wet-only precipitation (referred to as "PDM wet-only", collection only during rain events) was collected with a sampler from Eigenbrodt (NSA181/E HD-PE), especially designed for high altitudes. The precipitation at JFJ (JFJ bulk) was collected weekly from July 2015 to September 2016 (28/07/15-27/09/ 16). The collected precipitation was filled in precleaned $5 \mathrm{~L}$ high density polyethylene containers (HD-PE) (Supporting Information, SI). In the case of ice formation, the sampler was brought inside and capped with a lid until the rainwater was thawed (approximately 6-12 h), which was then transferred into the $5 \mathrm{~L}$ containers and shipped to Eawag, where they were immediately processed. The precipitation samples from PDM were also collected weekly, starting at the end of April 2015 (28/04/15-06/10/15; PDM bulk) and in 2016 between the end of April to September 2016 (26/04/16-13/09/16) (PDM bulk and wet-only). The collected precipitation was refrigerated $\left(4^{\circ} \mathrm{C}\right)$ and shipped to Eawag in precleaned $1 \mathrm{~L}$ HD-PE bottles every 6-8 weeks. At Eawag, the bottles were immediately processed.

Further precipitation samples were collected between February 2015 to November 2015 and January 2016 to March 2016 from the National Air Pollution Monitoring Network (NABEL) network (Table S2).

Sample Processing. The total amount of collected weekly precipitation $\left[P_{\mathrm{w}}\right]$ was determined by weight (Mettler Toledo XS6002S). The samples for quantification of elements (from JFJ, PDM, and NABEL) were filtered $(0.22 \mu \mathrm{m}$ syringe filters, Nylon-66). To test the optimum stabilization conditions the samples were stabilized once in acidic $\left(1 \% \mathrm{HNO}_{3}\right.$ (nitric acid $65 \%$, Suprapur, Merck, and once in alkaline conditions (0.5\% TMAH, tetramethylammonium hydroxide $25 \%$, Sigma-Aldrich). As similar results were obtained for both matrices, for $\mathrm{Se}, \mathrm{S}$, and $\mathrm{Br}$, only results for the $\mathrm{HNO}_{3}$ matrix are presented and discussed. Total concentrations of $\mathrm{Se}, \mathrm{Br}$, and $\mathrm{S}$ in these two different matrices are given in the SI Spreadsheet. However, I was only determined in TMAH solution. Samples for anion and trace element speciation were filtered $(0.22 \mu \mathrm{m})$ and refrigerated $\left(4{ }^{\circ} \mathrm{C}\right)$ in completely filled PP vials and glass tubes with Teflon lids $(5 \mathrm{~mL})$, respectively. For DOC determination, rainwaters were filtered with $0.45 \mu \mathrm{m}$ syringe filters (Nylon-66) and stored in glass bottles precleaned with ultrapure water. For carbon isotope determination, filtered ( 0.2 $\mu \mathrm{m}$ cellulose acetate, vacuum filtration) samples were filled in $10 \mathrm{~mL}$ glass vials with Teflon lids that were precleaned with hydrochloric acid ( $\mathrm{HCl}, 37 \%$, ROTIPURAN, Roth).

Total Analyses. Total elemental concentrations of Se, S, Br, and I were determined with ICP-MS (Agilent 8800 Triple Quadrupole ICP-MS; ICP-QQQ) in MS/MS mode using no gas mode (NG), hydrogen $\left(\mathrm{H}_{2} 5.0\right.$, PanGas, gas flow $5.5 \mathrm{~mL}$ $\left.\min ^{-1}\right)$ or oxygen $\left(\mathrm{O}_{2} 5.0, \mathrm{PanGas}, 30 \%\right)$ as reaction gas and the ISIS fast sample introduction system. Limits of detection (LOD) were $0.13 \mathrm{nM}$ and $0.05 \mathrm{nM}$ for ${ }^{78} \mathrm{Se}$ and ${ }^{80} \mathrm{Se}\left(\mathrm{H}_{2}\right.$ mode), $12 \mathrm{nM}$ for ${ }^{32} \mathrm{~S}\left(\mathrm{O}_{2}\right.$-reaction mode $), 8 \mathrm{nM}$ for ${ }^{81} \mathrm{Br}\left(\mathrm{H}_{2}\right.$ mode), and 0.06 and $0.04 \mathrm{nM}$ for ${ }^{127} \mathrm{I}\left(\mathrm{O}_{2}\right.$-mode and no gas mode), based on the $3 \sigma$-criterion of replicate analyses of at least 10 blank samples (Table S1, SI Spreadsheet). Further (trace) elements were determined ( $\mathrm{Na}, \mathrm{Mg}, \mathrm{K}, \mathrm{Ca}, \mathrm{As}, \mathrm{Si}, \mathrm{B}$, $\mathrm{Li}, \mathrm{V}, \mathrm{Cr}, \mathrm{Fe}, \mathrm{Cu}, \mathrm{Zn}, \mathrm{Sr}, \mathrm{Mo}, \mathrm{Cd}, \mathrm{Pb}$, and $\mathrm{U})$. More details are shown in SI Spreadsheet. Internal instrument drift was corrected by simultaneous detection of internal standards ( $50 \mathrm{ppb} \mathrm{Sc,} 5 \mathrm{ppb} \mathrm{Lu}, \mathrm{Rh}, \mathrm{Th}$ ). Instrument performance was checked with reference standards (NIST 1643f and a Fluka multi-anion standard solution for $\mathrm{S}$ and $\mathrm{Br}$ ), yielding recoveries of $101 \pm 9 \%$ for Se, $105 \pm 7 \%$ for $\mathrm{Br}$, and $128 \pm 23 \%$ for $\mathrm{S}$. Volume weighted mean (VWM) concentrations were calculated from elemental concentrations $\left(c_{i}\right)$ and precipitation volumes $\left(V_{i}\right)$ for the analyzed time period as follows:

$$
\mathrm{VWM}=\frac{\sum_{i}\left(c_{i} \times V_{i}\right)}{\sum_{i} V_{i}}
$$

Speciation Analyses with LC-ICP-QQQ. Selected precipitation samples from both sampling sites in the period from April to September 2016 were analyzed for Se, I, S, and $\mathrm{Br}$ speciation by advancing a method, which was initially developed to determine organic and inorganic Se species only. ${ }^{68,69}$ The speciation analyses were performed with liquid chromatography (Metrohm 940 Professional IC Vario or HPLC Agilent 1200 with multidraw kit) coupled to ICPQQQ. Chromatographic separation was performed using a mixed-mode column (HyperCarb $100 \times 4.6 \mathrm{~mm}, 5 \mu \mathrm{m}$ from Thermo Fisher) and an isocratic formic acid mobile phase (240 $\mathrm{mM}$ formic acid, formic acid 98-100\%, pro analysis, Merck) in $1 \% \mathrm{MeOH}$ (methanol, Chromanorm, VWR) at $\mathrm{pH}$ 2.3 (adjusted with 25\% ammonia solution, Suprapur, Merck). Injection volumes of 800 to $1200 \mu \mathrm{L}$ were used to achieve detectable peaks for the low concentrated rainwater samples (Figure S4). For ICP-QQQ detection, $\mathrm{O}_{2}$-mode was used which yielded comparable LODs for Se as reported for the former method using $\mathrm{H}_{2}{ }^{68,70}$ with $0.08 \mathrm{nM}$ for ${ }^{78} \mathrm{SeO}_{3}{ }^{2-}$ and ${ }^{78} \mathrm{SeO}_{4}{ }^{2-}$ vs 0.08 and $0.07 \mathrm{nM}$, respectively (SI). However, the advantage of measuring with $\mathrm{O}_{2}$ as reaction gas is the determination of $\mathrm{Se}, \mathrm{S}, \mathrm{Br}$, and I speciation in a single run. The LODs for the $\mathrm{S}, \mathrm{Br}$, and I species were as follows: respectively, 0.02 and $0.4 \mu \mathrm{M}$ for methanesulfonic acid (MSA) and ${ }^{32} \mathrm{SO}_{4}{ }^{2-}, 0.4$ and $1.1 \mathrm{nM}$ for $\mathrm{Br}^{-}$and $\mathrm{BrO}_{3}{ }^{-}$, and 0.1 and $0.4 \mathrm{nM}$ for $\mathrm{IO}_{3}^{-}$and $\mathrm{I}^{-}$allowing species determination at ultratrace levels (Table S1, SI Spreadsheet). The concentrations were determined using calibration series with mixed standards of stock solutions of selenite $\left(\mathrm{SeO}_{3}{ }^{2-}, \mathrm{SeIV}\right)$, selenate $\left(\mathrm{SeO}_{4}{ }^{2-}, \mathrm{SeVI}\right)$ (Spectracer), sulfate $\left(\mathrm{SO}_{4}{ }^{2-}\right.$, Fluka), MSA (Sigma-Aldrich), and sodium and potassium salts of bromide $\left(\mathrm{Br}^{-}\right)$, bromate $\left(\mathrm{BrO}_{3}^{-}\right)$(Sigma-Aldrich), iodate $\left(\mathrm{IO}_{3}{ }^{-}\right)$, and iodide $\left(\mathrm{I}^{-}\right)$(Sigma-Aldrich). All chromatographic peaks could be unambiguously identified (Figure S5). ICPQQQ and LC-ICP-QQQ data collection and processing were performed using MassHunter software.

Anion Quantification with IC and Calculated Sulfate Fractions. The anions (chloride $\left(\mathrm{Cl}^{-}\right)$, nitrate $\left(\mathrm{NO}_{3}{ }^{-}\right)$, sulfate $\left(\mathrm{SO}_{4}{ }^{2-}\right)$, bromide $\left(\mathrm{Br}^{-}\right)$, and phosphate $\left(\mathrm{PO}_{4}{ }^{3-}\right)$ were determined by anion exchange chromatography (Dionex ICS-2100, Thermo Fisher Scientific Inc., Dionex IonPac AG/ AS 19) with isocratic elution at $1 \mathrm{~mL} \min ^{-1}(40 \mathrm{mM} \mathrm{KOH}$, 


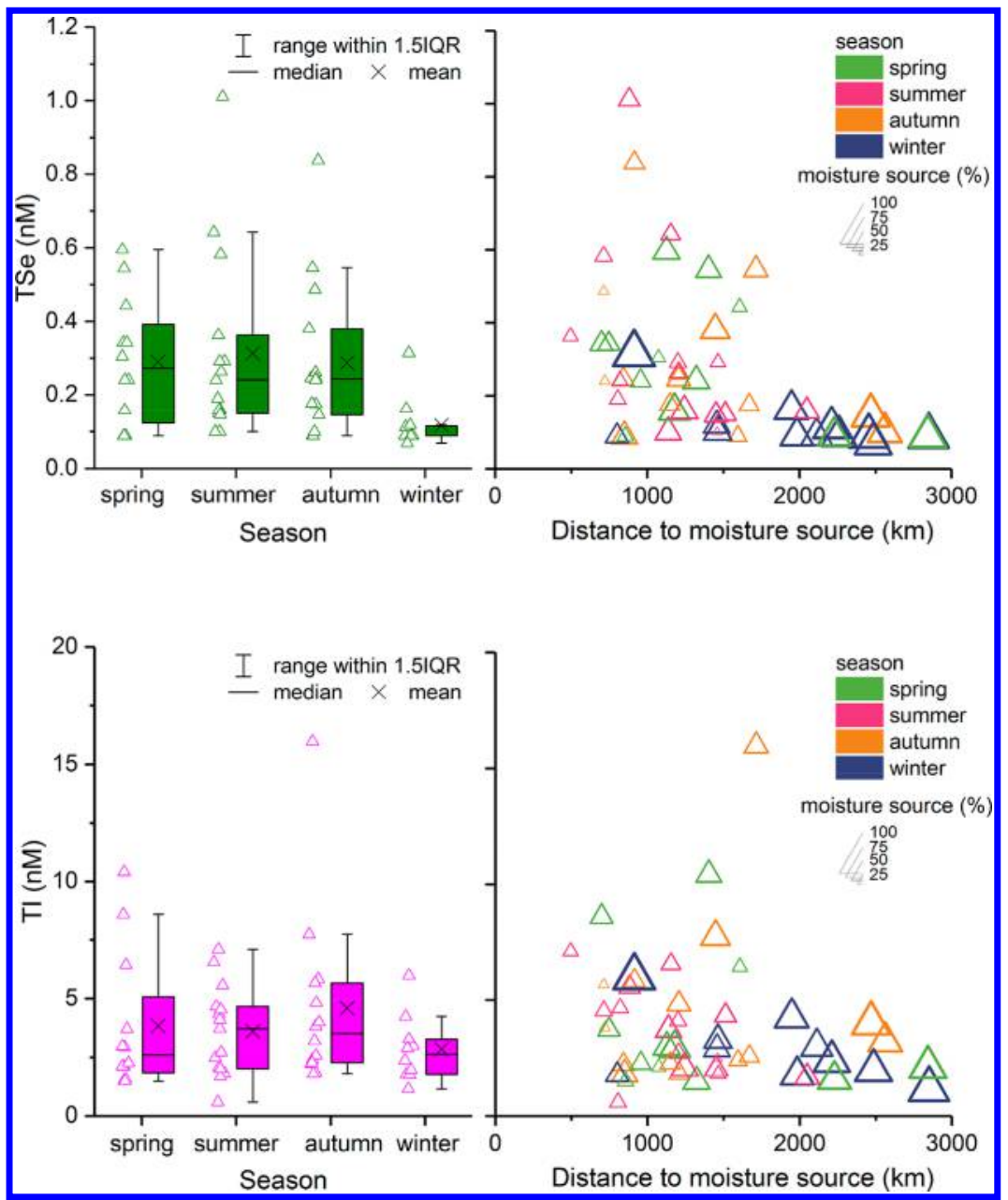

Figure 1. Seasonal averages for total concentrations of Se (TSe, in green) and I (TI, in pink) (panels on the left), and concentrations as a function of distance to moisture sources (panels on the right) for precipitation sampled at Jungfraujoch (JFJ) between July 2015 and September 2016 . The boxplots show the interquartile range (IQR), representing the middle $50 \%$ of the data, which fall between the upper quartile (75\% data below that score) and the lower quartile (less than $25 \%$ below that score). The median is indicated as a line and crosses show the averages. The whiskers are based on $1.5 \times$ IQR. The points depicted left of the boxplots show the corresponding data. The symbol sizes in the distance to moisture source plots is equivalent to the share of marine moisture, i.e., the larger the symbol, the higher percentage of marine moisture sources.

electrolytic eluent generator). Average LODs (based on two runs) were $0.41,0.20,0.21,0.29$, and $5.82 \mathrm{mg} \mathrm{L}^{-1}$ for $\mathrm{Cl}^{-}$, $\mathrm{NO}_{3}{ }^{-}, \mathrm{SO}_{4}{ }^{2-}, \mathrm{Br}^{-}$, and $\mathrm{PO}_{4}{ }^{3-}$, respectively. $\mathrm{Br}^{-}$and $\mathrm{PO}_{4}{ }^{3-}$ were below LOD. System control, data collection and processing were performed using Chromeleon. The $\mathrm{SO}_{4}{ }^{2-}$ concentrations along with $\mathrm{Mg}, \mathrm{Ca}$, and $\mathrm{Na}$ concentrations as determined by ICP-QQQ were further used to calculate different sulfate fractions (SI).

DOC, Carbon Isotope Determination, and Statistical Data Evaluation. Dissolved organic carbon (DOC) analyses were performed according to DIN EN $1484^{71}$ with a Shimadzu TOC-L CSH Analyzer (LOD $\left.0.5 \mathrm{mg} \mathrm{C} \mathrm{L}^{-1}\right){ }^{72-74}$ A detailed description of methods can be found in the SI. Statistical calculations were performed using SPSS, RStudio, and Origin 7.0. Correlations were performed as Spearman rank correlations (correlation coefficient indicated by $\rho$ ) and partial correlations restricted by precipitation volume (Pearson correlations, correlation coefficient indicated by $r$ ) and were all based on significance $p<0.05$.

Trajectory-Based Moisture Source and Loss Analysis. Air parcel backward trajectories were calculated using the $3 \mathrm{D}$ wind fields from two different atmospheric model data sets. $^{75,76}$ On a global scale 6-hourly data from the ERA-
Interim reanalyses ${ }^{77}$ of the European Centre for MediumRange Weather Forecasts (ECMWF) were used on a regular horizontal grid of $1^{\circ}$ resolution with 60 vertical levels. On the regional European scale the higher spatial and temporal resolution analysis data of the limited-area model COSMO ${ }^{78,79}$ was chosen to obtain a more realistic representation of the European orography and the coastal regions. Hourly COSMO data are provided operationally by MeteoSwiss with $7 \mathrm{~km}$ horizontal grid spacing and 60 vertical levels. The two trajectory data sets served as a basis to identify evaporative moisture sources of precipitation at the two sites JFJ and PDM following a Lagrangian procedure. ${ }^{80}$ For more information on the two atmospheric analysis data sets used, the trajectory calculation and the moisture source diagnostics see SI and Figures S1, S2, and S3.

From the air parcel trajectories and the moisture source information several characteristic quantities of atmospheric moisture cycling were derived:

1. Moisture source contributions from different regions: in particular, the share of continental vs marine moisture sources were calculated. For this, the gridded moisture uptakes as obtained from the moisture source 
$\operatorname{diagnostics}^{80}$ (see also SI Figures S1 and S2) were integrated over marine and continental areas respectively by using the land-sea mask of the ERA-Interim data set. The global ERA-Interim data set was used for this analysis because it covers the whole North Atlantic, which can represent a large share of the moisture sources at the two sites in particular in winter.

2. Weighted mean distance to moisture source: distance of the center of mass of ERA-Interim moisture sources from the sampling site.

3. Cumulative regional evaporation to precipitation ratio: relates the sum of all COSMO trajectory-based specific humidity changes associated with surface evaporation to the sum of all specific humidity changes associated with precipitation. This ratio provides an estimate of the history of moisture uptake vs moisture loss in the 5 days prior to arrival at the sampling site.

4. Chlorophyll a exposure at moisture source: Sea surface water chlorophyll a concentrations from the Ocean Color Climate Change Initiative data set, version 3.1 from the European Space Agency were used to estimate the air parcels' exposure to chlorophyll $a$ at the moisture source (SI for more details).

\section{RESULTS AND DISCUSSION}

Precipitation Chemistry and Moisture Source Data for Jungfraujoch (JFJ). Concentrations of Se, I, S, and Br. Measured concentrations and VWMs of Se, I, S, and Br for the four seasons are presented in Figure 1, SI Figures S6, S7 and Tables 1 and S5. Total concentrations ranged from 0.07 to $1.01 \mathrm{nM}$ (VWM $0.2 \mathrm{nM}$ ), 0.6-16.0 nM (VWM $2.7 \mathrm{nM}$ ), 0.5$21.7 \mu \mathrm{M}$ (VWM 3.16 $\mu \mathrm{M}$ ), and 5.3-154.1 nM (VWM 18.4

Table 1. Volume weighted means (VWM) for DOC, total S, Se, I, and Br for Jungfraujoch (JFJ) and Pic du Midi $(\mathrm{PDM})^{a}$

$\begin{array}{lrrrrr} & \text { annual } & \text { spring } & \text { summer } & \text { autumn } & \text { winter } \\ \text { DOC (mM) } & & & & & \\ \text { JFJ bulk } & 0.05 & 0.05 & 0.06 & 0.06 & 0.04 \\ \text { PDM bulk } & 0.11 & 0.11 & 0.12 & 0.07 & \\ \text { PDM wet-only } & 0.13 & 0.16 & 0.12 & 0.19 & \\ \text { S ( } \mu \text { M) } & & & & & \\ \text { JFJ bulk } & 3.16 & 5.51 & 2.77 & 2.30 & 1.41 \\ \text { PDM bulk } & 9.57 & 16.70 & 8.46 & 5.51 & \\ \text { PDM wet-only } & 7.01 & 11.14 & 6.08 & 11.46 & \\ \text { Se (nM) } & & & & & \\ \text { JFJ bulk } & 0.20 & 0.23 & 0.24 & 0.21 & 0.11 \\ \text { PDM bulk } & 0.65 & 0.96 & 0.59 & 0.54 & \\ \text { PDM wet-only } & 0.47 & 0.65 & 0.43 & 1.02 & \\ \text { Br (nM) } & & & & & \\ \text { JFJ bulk } & 18.42 & 12.99 & 16.38 & 15.99 & 34.43 \\ \text { PDM bulk } & 41.70 & 49.65 & 42.05 & 28.39 & \\ \text { PDM wet-only } & 70.54 & 90.33 & 65.70 & 118.46 & \\ \text { I (nM) } & & & & & \\ \text { JFJ bulk } & 2.71 & 2.26 & 2.65 & 3.28 & 2.62 \\ \text { PDM bulk } & 10.13 & 7.43 & 11.27 & 7.75 & \\ \text { PDM wet-only } & 8.41 & 9.73 & 8.02 & 15.83 & \\ & & & & & \end{array}$

${ }^{a}$ The volume weighted means were calculated from the sum of concentration $\times$ precipitation volume per event/sum of precipitation volumes within the sampling period. Note that for PDM no winter data are available.
$\mathrm{nM}$ ) for Se, I, S, and Br, respectively. Concentrations of Se, I, $\mathrm{S}$, and $\mathrm{Br}$ generally correlate positively with each other (with $\rho$ ranging from 0.5 to 0.8 , Tables S3 and S4), which may be explained by the volume of rainfall, i.e., the rainfall dilution effect, ${ }^{81}$ which leads to generally higher concentrations when rainfall volume is low, and vice versa. But when correcting for precipitation volume (Table S3, in addition to Spearman rank correlations, $r$ ranging from 0.3 to 0.6 ), partial correlations between the elements generally still remained, however at varying strength. Therefore, it is not the rainfall volume alone that explains observed correlations. Total concentrations of Se, $I$, and $S$ were higher in spring, summer, and autumn than in winter (see Figure 1, SI Figures S6 and S7, and Tables 1 and $\mathrm{S} 5)$. For $\mathrm{Br}$, concentrations in winter are about two times higher than those measured in the other seasons.

Origin of Precipitation. Contributions of marine and continental moisture sources for JFJ, established by trajectory-based calculations and moisture source diagnostics, are indicated in Figures S8 and S9. During winter, the percentage of marine moisture (on average $75 \%$; winter 2015/2016) is significantly higher than in the other seasons with on average $53 \%, 42 \%$, and $49 \%$ marine moisture sources for spring 2016, summer and autumn (averages for 2015/2016), respectively. Consequently, JFJ receives higher amounts of moisture derived from the continent in summer, spring and autumn than in winter (see Figure 2, Figure S9). This finding agrees well with previous studies, which showed that land moisture sources are dominant from late spring to summer, when air is transported from the planetary boundary layer to the high mountain stations. ${ }^{67}$ In winter, however, JFJ is mainly influenced by free tropospheric air transported over larger distances. ${ }^{67,82-89}$ To obtain more detailed information on marine moisture sources, these were further separated into Atlantic and Mediterranean sources (see SI). During winter, the Alps received markedly larger amounts of moisture from the Atlantic Ocean than in any of the other seasons ( $75 \%$ in winter vs $48 \%$ for spring to autumn). Contributions of Mediterranean moisture sources to JFJ were on average $11 \%$, with 6 and $7 \%$ on average in summer and winter and slightly higher shares in spring and autumn (16 and 12\%) (Figure S10, S11). These results in combination with lower total Se, I, and S concentrations in winter at JFJ suggest that for these elements land sources and potentially Mediterranean sources are important.

Concentrations of Dissolved Organic Carbon (DOC). To get further insights into biogenic versus anthropogenic sources, we determined DOC content in rainfall as well DOC- $\delta^{13} \mathrm{C}$. Concentrations of DOC over the entire sampling period ranged from 28 to $208 \mu \mathrm{M}$ (average $70 \mu \mathrm{M}$, see Table 1, S5) for JFJ. Similar to concentrations of Se, I, and S, DOC contents were higher in spring (average $61 \mu \mathrm{M}$ ), summer (average 85 $\mu \mathrm{M}$ ) and autumn (average $77 \mu \mathrm{M}$ ) compared to winter (average $44 \mu \mathrm{M}$ ) see SI Spreadsheet, differences tested with Wilcoxon Signed Ranks Test $(p<0.05)$. Concentrations of Se, $\mathrm{I}, \mathrm{S}$, and, to a lesser extent, $\mathrm{Br}$ correlate positively with DOC concentrations (Table S3, SI Spreadsheet). Also other studies reported higher DOC concentrations in summer than for winter as well as higher DOC levels in rain with continental sources compared to rain with marine sources. ${ }^{90-94}$

Correlations between $\mathrm{Se}, \mathrm{I}, \mathrm{S}, \mathrm{Br}$, and Sources of DOC. For JFJ, DOC- $\delta^{13} \mathrm{C}$ values range from -26.1 to $-34.3 \%$ in the complete sampling period with mean standard deviations of $0.8 \%$ for replicate analyses. Statistical analyses (MannWhitney and Kolmogorov-Smirnov test) reveal seasonal 


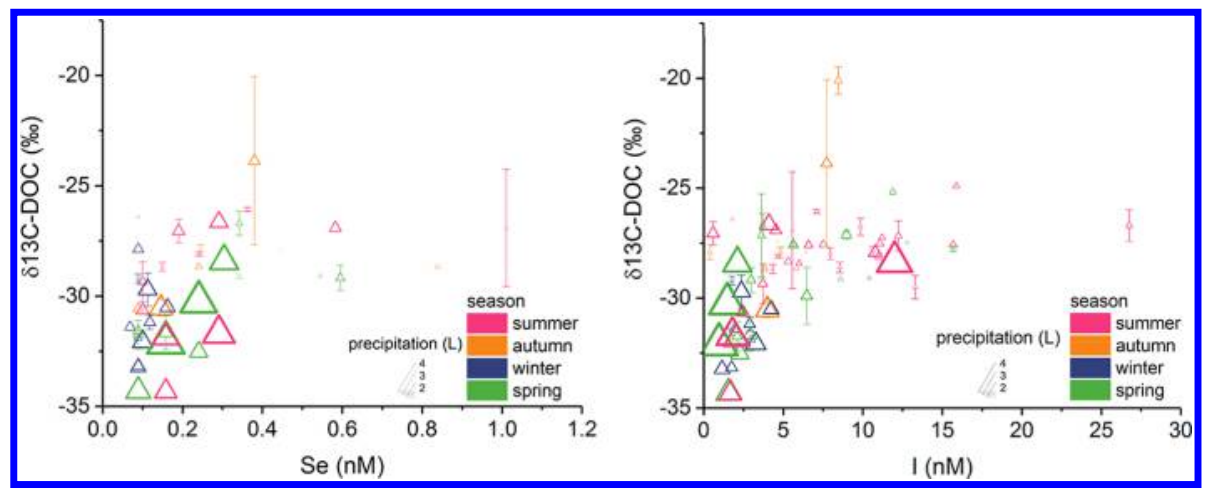

Figure 2. Correlations between DOC- $\delta^{13} \mathrm{C}$ values and Se $(\rho=0.6, p<0.05)$ and I $(\rho=0.6, p<0.05)$ for the entire JFJ data set (Table S3). The symbol size indicates the volume of collected precipitation. Corresponding figures for PDM are in Figure S14.

differences with greatest depletion (most negative values) in winter. Average values follow the order winter $(-31.3 \% 0)<$ spring $(-30.3 \% 0)<$ autumn $(-28.7 \%$ ) and $=$ summer $\left(-28.4 \%\right.$ ) (see Figure S12). For $\mathrm{CO}_{2}$ data, more depleted values of $\delta^{13} \mathrm{C}$ in winter compared to summer (on the order of $4-6 \%$ ) have previously been described for $\mathrm{JFJ}^{95,96}$ and other continental northern midlatitude sites ${ }^{97}$ and Beijing. ${ }^{98}$ These trends have been explained by a larger contribution of fossil fuel combustion in winter (isotopically depleted values) and a larger biogenic source contribution (e.g., vegetation) in spring and summer (enriched values). A larger contribution of fossil fuel derived $\mathrm{OC}$ in winter was also observed for aerosols at JFJ. ${ }^{99}$ Furthermore, DOC- $\delta^{13} \mathrm{C}$ is weakly correlated to the moisture source of precipitation ( $\rho=-0.4$ for marine, $\rho=0.4$ for continental and $\rho=0.3$ ) for Mediterranean moisture sources (see Table S3). These results agree with a higher terrestrial moisture source contribution in summer, and potentially indicate a contribution of OC derived from vegetation transported via anabatic winds. ${ }^{84}$ However, further detailed analyses are required to determine the exact sources of dissolved organic matter (DOM) in our samples as, e.g., Ceburnis et al. $(2011)^{100}$ state that ${ }^{13} \mathrm{C}$ determination alone, cannot completely distinguish fossil fuel sources from biogenic sources.

For the whole analyzed time period, I and Se correlate positively with DOC- $\delta{ }^{13} \mathrm{C}$ (Figure 2 and Table S3: $\rho=0.6, r=$ 0.4 , both for I and Se) and the strength of these correlations exceeds the strength of positive correlations between DOC$\delta^{13} \mathrm{C}$ and continental moisture sources (Table S3). Also, correlations between DOC- $\delta^{13} \mathrm{C}$ and $\mathrm{S}$ and $\mathrm{Br}$ are present, although generally at a lower strength as for I and Se (Figure S13 and Table S3). These results may indicate that particularly I and Se are related to the source of DOM, and that these elements have a more dominant biogenic terrestrial source in summer, in addition to other land sources including anthropogenic sources. However, this hypothesis requires further study. In contrast, during wintertime, no correlations of Se, I, S, and $\mathrm{Br}$ with DOC- $\delta^{13} \mathrm{C}$-values are observed but instead, strong correlations with seasalt sulfate $\left(\right.$ ss- $\left.\mathrm{SO}_{4}\right)$ (e.g., $\rho$ $=0.9$ and $r=1$ for $\mathrm{I} ; r=0.9$ for $\mathrm{Br}$ ) (Table S3, SI Spreadsheet). This finding indicates a more dominant marine source of $\mathrm{I}$ and $\mathrm{Br}$ in winter, agreeing with higher contributions of Atlantic moisture sources.

Correlations of $\mathrm{Se}, \mathrm{I}, \mathrm{Br}$, and $\mathrm{S}$ to Chlorophyll a Exposure. To investigate a potential link between precipitation chemistry and emissions of volatile organic compounds of Se, I, Br, and S from bioproductive surface water bodies (marine environments and lakes), we tested if there was a correlation between chlorophyll $a$ exposure at the moisture source and $\mathrm{Se}, \mathrm{I}, \mathrm{Br}$, and $S$ concentrations in precipitation. For JFJ, we found that chlorophyll $a$ exposure at the moisture source correlates positively with continental moisture sources $(\rho=0.6, r=0.5)$ and the fraction of moisture uptake over lakes $(\rho=0.4, r=0.6$, SI Spreadsheet). However, no significant correlations are present between chlorophyll $a$ exposure at the moisture source and $\mathrm{Se}, \mathrm{I}, \mathrm{S}$, and $\mathrm{Br}$, indicating that biogenic emissions of these elements from surface waters do not represent a dominant source of these elements in precipitation at JFJ.

Precipitation Chemistry and Moisture Source Data for Pic du Midi (PDM). Concentrations of $\mathrm{Se}, \mathrm{l}, \mathrm{Br}$, and $\mathrm{S}$ and Origin of Precipitation. As compared to JFJ, the Pic du Midi (PDM) site receives more precipitation with marine moisture. In general, PDM receives larger amounts of Atlantic moisture than JFJ as is expected because PDM is closer to the North Atlantic, i.e., the shortest direct distance is $150 \mathrm{~km}$ for PDM compared to $625 \mathrm{~km}$ for JFJ. At PDM two different samplers were used to analyze bulk deposition and wet deposition only. However, at JFJ rainfall data was only obtained using a bulk sampler (same type as used at PDM). Therefore, for PDM only precipitation data derived from the bulk sampler are discussed, to enable a comparison between the two sites. In contrast to JFJ, for PDM no data are available for winter and only limited data for autumn. Total concentrations of Se, I, S, and Br over the whole sampling period ranged from 0.16 to $2.33 \mathrm{nM}(0.62 \pm 0.41$, VWM 0.65 $\mathrm{nM}), 0.4-26.8 \mathrm{nM}(9.4 \pm 5.1 \mathrm{nM}$, VWM $10.1 \mathrm{nM}), 2.2-44.3$ $\mu \mathrm{M}(11.4 \pm 8.3$, VWM $1.1 \mu \mathrm{M})$, and 14.9-98.8 $\mathrm{nM}(44.0 \pm$ $19.2 \mathrm{nM}, 41.7 \mathrm{nM}$ ), respectively (Table $1, \mathrm{~S} 5$ ). When the same seasons are compared (see Figures S6 and S7), it can be seen that concentrations of these elements are generally higher in rainfall at PDM than at JFJ. These differences are likely not only explained by the difference in elevation as very low concentrations were also found at lower altitude stations in Switzerland (see Table 1, S5). During spring, precipitation with Atlantic moisture sources was always larger than $56 \%$ $(56-71 \%)$, whereas during summer, this value ranged from 18 to $79 \%$ and was thus more variable (F-test, $p<0.05$ ). Similar to JFJ, the contribution of precipitation with continental moisture sources were highest in summer, i.e., 21 to $69 \%$ (on average 44\%) (see SI Spreadsheet, Figure S8).

Concentrations of DOC and Sources of DOC in Rainfall (DOC- $\delta^{13} C$ Values). As for $\mathrm{Se}, \mathrm{I}, \mathrm{S}$, and $\mathrm{Br}$, also DOC concentrations at PDM are significantly higher than at JFJ (Median and Mann-Whitney test, $p<0.05$ ). For samples with 


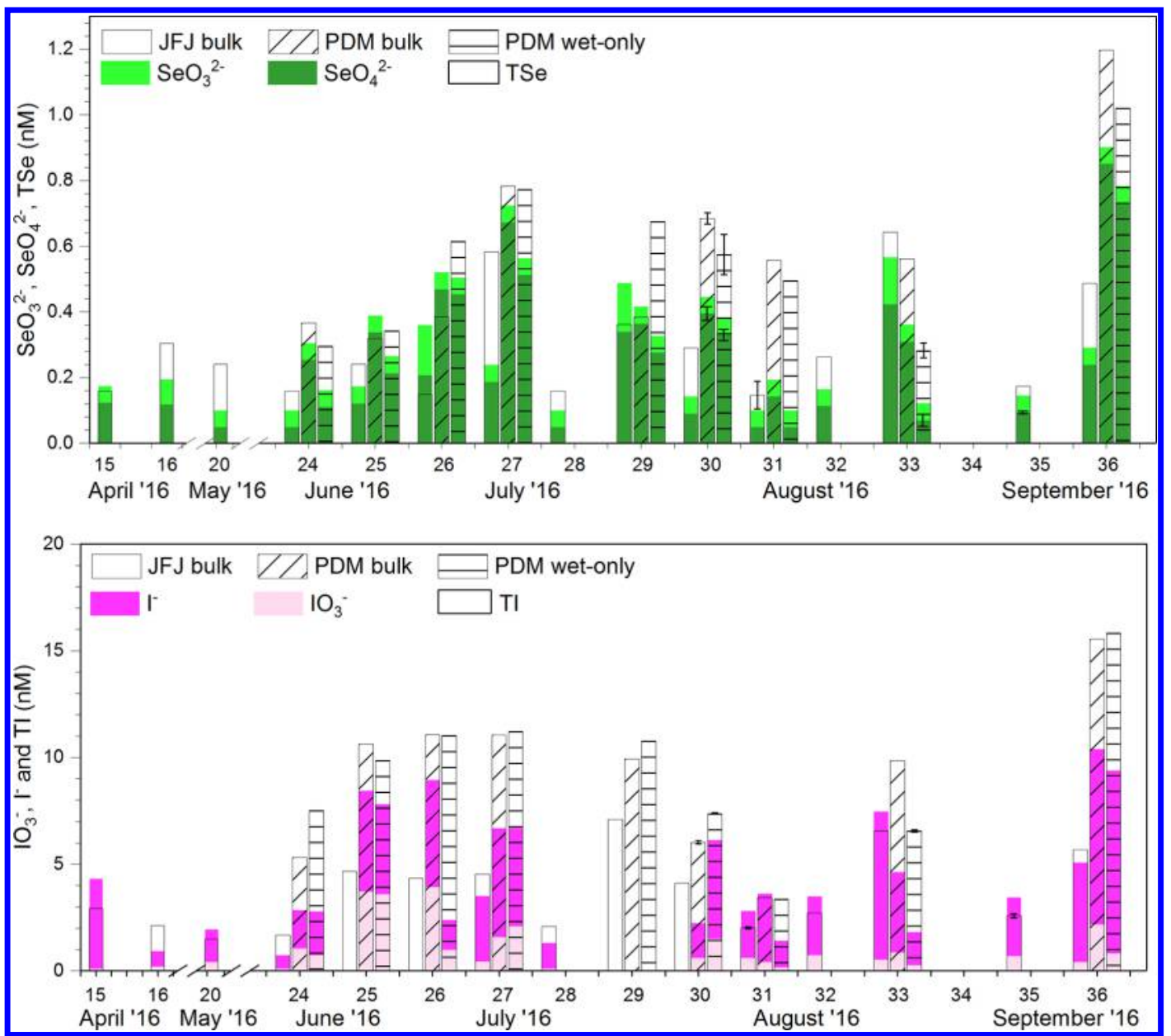

Figure 3. Total concentrations and speciation for selenium (total Se (TSe), selenite $\left(\mathrm{HSeO}_{3}{ }^{-}\right.$), and selenate $\left(\mathrm{SeO}_{4}{ }^{2-}\right)$, green; upper plot) and iodine (total iodine (TI), iodate $\left(\mathrm{IO}_{3}^{-}\right)$and iodide $\left(\mathrm{I}^{-}\right)$, pink; lower plot), for weekly precipitation samples collected at JFJ (bulk sampler) and PDM (bulk and wet-only samplers) from April 2016 to September 2016 (week 15 to 36). The difference between TSe and TI and the sum of the identified species (displayed in white) is operationally defined as the fraction of unidentified species. White bars indicate that no speciation data is available. Selected samples were analyzed in triplicates, for these samples standard deviations are indicated.

higher contributions of rainfall from marine origin, lower average DOC contents were found ( $73 \mu \mathrm{M}$ for samples with an oceanic moisture contribution $>50 \%$ vs $129 \mu \mathrm{M}$ for the other samples) ( $t$-test and Mann-Whitney test for medians). Therefore, it is likely that the highest levels of DOC result from land sources. Compared to JFJ, DOC- $\delta^{13} \mathrm{C}$-values from PDM span a smaller range, from -20.1 to $-29.9 \%$ (average $\mathrm{SD} \pm 0.7 \%$ ) for the complete sampling period in 2015 and 2016. There were no significant differences in average DOC$\delta^{13} \mathrm{C}$-values for spring and summer and when DOC- $\delta^{13} \mathrm{C}$ data for the same weeks in summer for PDM and JFJ are compared, there is no statistically significant difference between both sites. Interestingly, at PDM, highest $\mathrm{DOC}-\delta^{13} \mathrm{C}$-values were measured when Atlantic contributions to rainfall were lowest (in summer) but also when Atlantic contributions were highest (in spring and early summer) (Figure S14). Furthermore, for continental moisture source contributions larger than $40 \%$ (summer), DOC- $\delta^{13} \mathrm{C}$ values correlate positively to continental and Mediterranean moisture sources $(\rho=0.7, r=0.7$ for both) and negatively with Atlantic moisture sources $(\rho=-0.9, r=$ -0.7) (see Table S4) as was also observed for JFJ, and which could be interpreted again by higher contributions of DOC derived from vegetation. In contrast, higher DOC- $\delta^{13} \mathrm{C}$ values in spring and early summer associated with higher contribu- tions of Atlantic moisture sources could point to contributions of marine biogenic DOC sources as described, e.g., in Avery et al. ${ }^{90}$ and Gromov et al. ${ }^{90,101}$ However, on average the values of DOC- $\delta^{13} \mathrm{C}$-values for PDM, are lower than reported average values for marine biogenic DOC emissions i.e., $-22 \% 0^{101,102}$ or $-18 \%$ to $-20 \%,{ }^{90}$ which is a further indication for mixed continental and marine DOC sources at PDM.

Correlations between $\mathrm{Se}, \mathrm{I}, \mathrm{S}, \mathrm{Br}$, and Sources of DOC. In contrast to JFJ, there are no correlations between total concentrations of Se, S, Br, DOC- $\delta^{13} \mathrm{C}$ levels, and origin of precipitation for PDM (see Table S4). For I, there is a moderately strong correlation with the continental share of precipitation moisture sources $(\rho=0.4)$, which is more pronounced for periods when continental moisture sources exceeded $40 \%$ (mainly in summer) $(\rho=0.8, r=0.7)$. For these events, I concentrations also correlate positively with DOC$\delta^{13} \mathrm{C}$ levels $(\rho=0.8, r=0.8)$ which may indicate a biogenic land source in summer, however, again, this needs further investigation. Further information on precipitation chemistry can be found in the SI.

Correlations of $\mathrm{Se}, \mathrm{I}, \mathrm{Br}$, and S to Chlorophyll a Exposure. For PDM, chlorophyll $a$ exposure at the moisture source is positively correlated to marine $(\rho=0.5)$ and Atlantic moisture origin $(\rho=0.4)$ and negatively correlated to continentally 
derived moisture $(\rho=-0.5)$ (see Table S4). This indicates that predominantly air masses derived from the marine environment have traveled over chlorophyll $a$ enriched marine surface waters. Furthermore, positive correlations are found between chlorophyll $a$ exposure and $S(\rho=0.5, r=0.5)$ and Se $(r=0.6)$, which could indicate a contribution of a marine biogenic source for these elements at PDM. In the bioproductive period (April-September 2016), the correlation with chlorophyll $a$ exposure holds for Se $(r=0.7)$ but not for $S$. This finding might be related to the so-called summerparadox, i.e., the time lag between maxima in marine phytoplankton biomass and DMS emissions, which has been reported for tropical to polar latitudes, ${ }^{103,104}$ however, this needs further investigation. In addition, also relatively strong

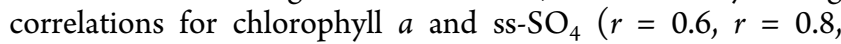
respectively) are found in the bioproductive period, which may generally indicate marine inputs.

Speciation. S and Se Speciation. At both JFJ and PDM, only inorganic species of Se, I, S, and $\mathrm{Br}$ were detected, except for MSA, an oxidation product of DMS Figure S15. Figure 3 and Figure S15 indicate determined species as well as total concentrations. As expected, the majority of $\mathrm{S}$ (total $\mathrm{S}$ concentration) is present as sulfate $\left(\mathrm{SO}_{4}{ }^{2-}\right)$, ranging from 94.1 to $99.6 \%(8.4-854 \mu \mathrm{g} \mathrm{S})$. MSA is present in amounts of 0.5 to $5.9 \%(0.1-12.6 \mu \mathrm{g} \mathrm{S})$. For JFJ, we calculated an average contribution of ss-SO $\mathrm{SO}_{4}$ and non sea-salt sulfate $\left(\mathrm{nss}-\mathrm{SO}_{4}\right)$ of 41 and 59\%, which is not much different than the values for PDM, i.e., with on average $50 \% \mathrm{ss}-\mathrm{SO}_{4}$ and nss- $\mathrm{SO}_{4}$ contributions (SI Spreadsheet). Seasonality of $\mathrm{S}$ speciation (no data for winter) was most pronounced for MSA, having contributions to total $S$ at JFJ of $0.9-5.4 \%$ for summer $>0.5-4.2 \%$ for spring $>0.7-$ $1.4 \%$ for autumn reflecting the relation between MSA and biogenic DMS productivity. However, as also $\mathrm{SO}_{4}{ }^{2-}$ is an important product of DMS oxidation, formed in a different reaction pathway than MSA, which is formed via both gas- and aqueous-phase reactions, ${ }^{64}$ the concentrations of MSA cannot be directly linked to DMS fluxes. Previously, the ratio between $100 \times \mathrm{MSA}$ and nss-SO $\mathrm{SO}_{4}$ was used as a proxy for marine air masses. This ratio was found to be higher in marine air $(3.3 \pm$ 2.4) than in continental air $(1.8 \pm 0.8),{ }^{105}$ largely due to the relatively lower nss-SO $\mathrm{S}_{4}$ levels in marine air masses. ${ }^{105}$ This trend is also observed in our data as marine moisture sources correlate positively to the $100 \times \mathrm{MSA} / \mathrm{nss}^{-\mathrm{SO}_{4}}$ ratio both for JFJ $(\rho=0.5)$ and PDM $(\rho=0.7)$ (SI Spreadsheet).

As was also reported in previous studies e.g., ${ }^{54} \mathrm{Se}$ is mainly present in its most oxidized form, $\mathrm{SeO}_{4}{ }^{2-}$ with on average contributions of $65 \pm 12 \%$ at JFJ and $84 \pm 8 \%$ at PDM. The concentrations range from < LOD $(0.07 \mathrm{nM})$ to $0.42 \mathrm{nM}$ $(48-82 \%, 0.15 \pm 0.1 \mathrm{nM})$ at JFJ and from 0.14 to $0.85 \mathrm{nM}$ (66-94\%; $0.41 \pm 0.19 \mathrm{nM}$ ) for PDM (see Figure 3, SI Spreadsheet). The concentration of the more reduced species, $\mathrm{SeO}_{3}{ }^{2-}$ is < LOD $(0.08 \mathrm{nM})$ to $0.15 \mathrm{nM}$ for JFJ and < LOD to $0.19 \mathrm{nM}$ LOD for PDM. Generally, the fraction of $\mathrm{SeO}_{3}{ }^{2-}$ relative to $\mathrm{SeO}_{4}{ }^{2-}$ is higher for JFJ samples $(18-52 \%)$ than for PDM (6-34\%). However, the concentration of $\mathrm{SeO}_{4}{ }^{2-}$ correlates positively to the continental share of moisture sources of precipitation (JFJ: $\rho=0.5$, PDM: $\rho=0.6$ ) (see Figure S16, SI Spreadsheet), which indicates that the more continental location of JFJ does likely not explain the larger share of $\mathrm{SeO}_{3}{ }^{2-}$ at JFJ than at PDM. The predominance of inorganic anionic species indicates that any small organic Se compounds present have been oxidized in the atmosphere, which can be expected considering the short lifetime of
DMSe. ${ }^{23}$ However, for many samples, the total amount of quantified species is lower than the total Se concentrations and therefore missing fractions occur. For Se unidentified fractions make up to 59\% (of total Se) for JFJ and 65\% for PDM (for wet-only sampler even up to $80 \%$ ). These unidentified fractions may be explained by larger organic molecules, which could not be detected using our method. Therefore, further research is required to elucidate the nature of these unidentified species.

I and $\mathrm{Br}$ Speciation. Iodide $\left(\mathrm{I}^{-}\right)$is the main species of $\mathrm{I}$ that was found, with concentrations ranging from 0.6 to $6.9 \mathrm{nM}$ $(78-97 \% ; 2.7 \pm 1.8 \mathrm{nM})$ at JFJ and from 1.6 to $8.2 \mathrm{nM}(56-$ $88 \% ; 4.2 \pm 2.1 \mathrm{nM})$ for PDM. Iodate $\left(\mathrm{IO}_{3}{ }^{-}\right)$concentrations range from 0.1 to $0.7 \mathrm{nM}(2-21 \%, 0.4 \pm 0.2 \mathrm{nM})$ for JFJ and between 0.3 and $3.9 \mathrm{nM}(11-44 \%, 1.8 \pm 1.4 \mathrm{nM})$ for PDM (see Figure S15), indicating that the share of $\mathrm{IO}_{3}{ }^{-}$is higher at PDM than at JFJ in the analyzed time period (AprilSeptember). These results are in line with previous findings indicating generally higher fractions of $\mathrm{IO}_{3}{ }^{-}$in marine-derived precipitation compared to continental precipitation, ${ }^{12,20,37,106}$ however, we did not find any significant trend between the moisture sources of precipitation and I speciation, neither for PDM nor for JFJ (Figure S16). The higher share of $\mathrm{I}^{-}$may be explained by more reduced forms of I, e.g., $\mathrm{CH}_{3} \mathrm{I}$, derived from local sources, which undergo photolysis and oxidation in the gas-phase, producing HOI and OI, among others. These species are expected to be taken up in the aqueous phase, where they can be transformed to $\mathrm{I}^{-}$via reaction with sulfite. ${ }^{17}$ Another explanation for the lower share of $\mathrm{IO}_{3}^{-}$at JFJ is reduction of $\mathrm{IO}_{3}{ }^{-}$in the presence of $\mathrm{DOM}$, i.e., $\mathrm{I}^{-}$formation was demonstrated to occur via reduction of $\mathrm{IO}_{3}^{-}$in the presence of DOM at low $\mathrm{pH}^{17,107}$ Therefore, even small changes in $\mathrm{pH}$ and DOM content and type may lead to differences in $\mathrm{I}^{-}$to $\mathrm{IO}_{3}^{-}$ratios between different locations. Apart from $\mathrm{I}^{-}$and $\mathrm{IO}_{3}{ }^{-}$, there were also variable fractions of unidentified I. For PDM the share of missing species ranged from -4 to $63 \%$ (average $34 \pm 22 \%$ ) and for JFJ this fraction ranged from -47 to $57 \%(0 \pm 37 \%)$. Negative values are explained by a higher sum of species than totals for 7 out of 13 events, which is likely explained by the very low I concentrations leading to higher uncertainties. The fraction of unidentified I likely indicates the occurrence of species which could not be resolved by our method, e.g., complexed organics or aerosols as has been suggested previously. $^{12,20,37,106,108,109}$

In contrast to $\mathrm{I}, \mathrm{Br}$ is only present as bromide $\left(\mathrm{Br}^{-}\right)$and bromate $\left(\mathrm{BrO}_{3}{ }^{-}\right)$concentrations are below the $\mathrm{LOD}(1.1 \mathrm{nM})$ (Figure S15, SI Spreadsheet). As total Br levels are generally higher for PDM as for JFJ, also $\mathrm{Br}^{-}$levels are higher, i.e., on average $41.6 \pm 16.3 \mathrm{nM}$ vs $12.7 \pm 6.2 \mathrm{nM}$, respectively. Dissolved total $\mathrm{Br}$ in rainwaters from Plynlimon (Wales) was also found to be present as $\mathrm{Br}^{-110}$ however, concentrations were much higher (on average $163 \mathrm{nM}$ ) due to direct marine influence. The absence of $\mathrm{BrO}_{3}{ }^{-}$, in contrast of $\mathrm{IO}_{3}{ }^{-}$, is explained by the fact that $\mathrm{BrO}_{3}{ }^{-}$formation is a slow process and also not achievable by all main atmospheric oxidants. ${ }^{21}$ Similar to Se, I, and S, also for $\mathrm{Br}$, fractions of missing species are found, i.e., up to $53 \%$ for JFJ (mean $21 \%$ ) and up to $63 \%$ for PDM (mean 34\%). Again, these unidentified fractions may be explained by the presence of organic species, as was previously suggested. ${ }^{37}$

Marine versus Terrestrial Sources. The relationships between elemental concentrations in combination with 


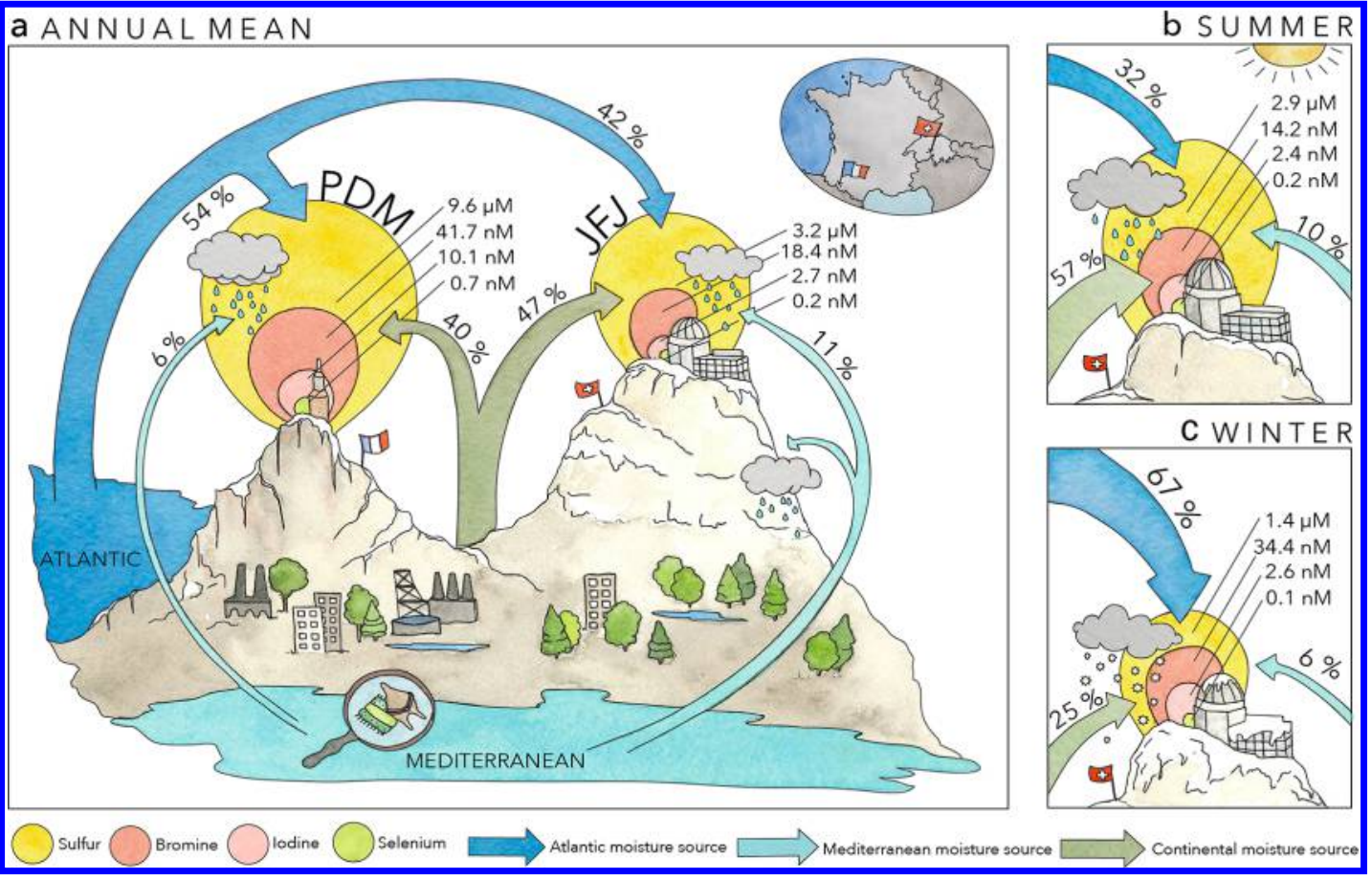

Figure 4. Schematic diagram summarizing the main results, i.e., annual average concentrations of $\mathrm{I}, \mathrm{Se}, \mathrm{Br}$, and $\mathrm{S}$ and contributions of moisture sources for both investigated JFJ (July 28, 2015 to September 27, 2016) and PDM (April 28, 2015 to September 19, 2016). (a) Volume weighted mean concentrations of $\mathrm{I}, \mathrm{Se}, \mathrm{Br}$, and $\mathrm{S}$, are indicated in ellipses and average annual contribution of moisture sources from the Atlantic Ocean, Mediterranean Sea, and the continent are indicated for the entire sampling period for JFJ (on the right side) and PDM at the left (note that for PDM no winter data are available), (b) average volume weighted mean concentrations and moisture source contributions for JFJ in summer only, and (c) winter only.

information on the origin of precipitation, indicates that in winter when marine moisture source contributions are highest, concentrations of I, Se, and S at JFJ are lowest. It is likely that the concentrations in winter are low due to a lack of continental sources but also due to a potential rainfall dilution effect during more long-range atmospheric transport. In contrast, $\mathrm{Br}$ concentrations are higher in winter than in other seasons. Furthermore, $\mathrm{Br}$ concentrations correlate strongly with ss-SO $\mathrm{SO}_{4}$ (see Table S3). This may indicate transport of $\mathrm{Br}$ via submicrometer sea-salt aerosols, as has been reported previously. ${ }^{111}$ Sources of $S$ and Se in winter cannot be resolved but these elements may also have been derived from marine (submicron) aerosols (strong correlation to I and $\mathrm{Br}$, which may indicate similar transport pathways) and/or continental emissions (correlation with DOC in winter time, e.g., DOC derived from fossil fuel emissions). In the bioproductive period, we find indications that $\mathrm{Se}, \mathrm{I}, \mathrm{S}$, and $\mathrm{Br}$ have terrestrial sources (e.g., positive correlations with nss- $\mathrm{SO}_{4}$, see Table S3) that are related to a biogenic source of DOC- $\delta^{13} \mathrm{C}$, in addition to marine contributions for $\mathrm{I}$ and $\mathrm{Br}$ (positive correlations with ss-SO $\mathrm{SO}_{4}$, see Table S3). Similar to I and Se, terrestrial methyl bromide $\left(\mathrm{CH}_{3} \mathrm{Br}\right)$ emissions, e.g., from coastal ecosystems, organic-rich soils, ${ }^{112}$ vegetation, ${ }^{33,113,114}$ and coastal wetlands ${ }^{33}$ were found to be important. Butler (2000) suggested that terrestrial sources could balance atmospheric Br budgets, for which $40 \%$ of the sources are missing. ${ }^{112}$ Also, the ratio of $\mathrm{Br} / \mathrm{I}$ concentrations is generally higher in the JFJ samples than in the PDM samples (Table 1), which may imply that relatively more $\mathrm{Br}$ is derived from terrestrial sources.

At PDM, continental trace element contributions are less pronounced due to the generally higher contribution of marine sources. However, when continental moisture source con- tribution was high $(>40 \%)$, we found indications of terrestrial sources of I, linked to a biogenic source of DOC- $\delta^{13} \mathrm{C}$ as well as nss- $\mathrm{SO}_{4}$ correlations with $\mathrm{I}, \mathrm{Se}$, and $\mathrm{S}$ and $\mathrm{DOC}-\delta^{13} \mathrm{C}$ (see Table S4).

In conclusion, our data suggest mixed marine and continental source contributions for $\mathrm{I}, \mathrm{Se}, \mathrm{Br}$, and $\mathrm{S}$ at both sites, however, there are clear seasonal differences, illustrated in Figure 4. Higher shares of continental moisture sources in spring, summer, and autumn, and higher concentrations of I and $\mathrm{Se}$ at JFJ in these seasons suggests a more local cycling, i.e., terrestrial emissions, atmospheric transport, and deposition, of these elements. The link between concentrations of I, Se, Br, and $S$ and the source of dissolved organic matter (i.e., correlations with DOC- $\delta^{13} \mathrm{C}$ values), especially in summertime and when continental moisture sources dominate, potentially indicates biogenic land emissions, although this needs further investigation. As emissions from terrestrial environments are still largely unknown due to the heterogeneous nature of terrestrial landscapes, more work needs to be done in measuring and understanding these trace element emissions from different types of environments. When this information becomes available, biogeochemical models, aimed at predicting the cycling and distribution of I and Se, can be refined, enabling more accurate predictions of environmental sources and sinks of $\mathrm{I}$ and $\mathrm{Se}$, and especially their inputs into agricultural soils and terrestrial food chains.

\section{ASSOCIATED CONTENT}

\section{Supporting Information}

The Supporting Information is available free of charge on the ACS Publications website at DOI: 10.1021/acs.est.8b05533. 
Text file containing clarifications and more detailed information on the methods and results section and additional Figures S1-S12 and Tables S1-S5 (PDF)

Spreadsheet with the data presented in this manuscript (XLSX)

\section{AUTHOR INFORMATION}

\section{Corresponding Author}

*E-mail: lwinkel@ethz.ch.

ORCID

Jeroen E. Sonke: 0000-0001-7146-3035

Lenny H. E. Winkel: 0000-0001-7586-7256

Notes

The authors declare no competing financial interest.

\section{ACKNOWLEDGMENTS}

We thank the International Foundation High Altitude Research Stations Jungfraujoch and Gornergrat for the opportunity to collect rainwater samples at Jungfraujoch and the custodians at Jungfraujoch (Joan and Martin Fischer and Maria and Urs Otz) and technical staff at UMS 831 Pic du Midi Observatory for their support. S. Preunkert and M. Legrand are acknowledged for their help with for $\mathrm{SO}_{4}$-fraction calculations. We thank S. Henne for preliminary trajectory calculations, R. Kretzschmar, F. Conen, A. Feinberg, U. von Gunten, E. Stopelli, and J. Tolu for constructive discussions and feedback. We are grateful to M. Bueno for advice on Se speciation analyses and for carrying out preliminary analyses. M. Fleischmann, M. Kübler, J. Riedo, N. Pfenninger, C. Schlierenzauer, C. Stengel, N. Spichtig, and S. Wellauer are acknowledged for lab and analytical support, S. Bernasconi and M. Jäggi for isotope determination, P. Béziat for artwork and L. Widmer for final editing. Furthermore, the National Air Pollution Monitoring Network (NABEL, Empa and BAFU) is acknowledged for providing rainwater samplers and $\mathrm{C}$. Zellweger and E. Wettstein for IC determination of the NABEL samples. We thank A. und S. Lück and N. Dubois for providing the bulk samplers. Metrohm Switzerland AG and Agilent technologies are thanked for instrumental support. This project was funded by the Swiss National Science Foundation (SNSF project 200021_156586).

\section{REFERENCES}

(1) Adamson, P. Vitamin \& Mineral Deficiency, A Global Progress Report; Ottawa, Ontario, Canada, 2004.

(2) Zimmermann, M.; Trumbo, P. R. Iodine. Adv. Nutr. 2013, 4 (2), 262-264.

(3) Fordyce, F. M. Selenium Deficiency and Toxicity in the Environment. In Essentials of Medical Geology; Selinus, O., Ed.; Springer: Dordrecht, 2012; pp 375-416.

(4) Boron, W. F.; Boulpaep, E. L. Medical Physiology: A Cellular and Molecular Approach, $2^{\text {nd }}$ ed.; W.B. Saunders: Philadelphia, PA, 2003; p 1319.

(5) Fuge, R. Soils and Iodine Deficiency. In Essentials of Medical Geology; Springer: Netherlands, 2012; pp 417-432.

(6) Cone, J. E.; Del Rio, R. M.; Davis, J. N.; Stadtman, T. C. Chemical characterization of the selenoprotein component of clostridial glycine reductase: identification of selenocysteine as the organoselenium moiety. Proc. Natl. Acad. Sci. U. S. A. 1976, 73 (8), 2659-2663.

(7) Castellano, S.; Gladyshev, V. N.; Guigó, R.; Berry, M. J. SelenoDB 1.0: a database of selenoprotein genes, proteins and SECIS elements. Nucleic Acids Res. 2008, 36 (S1), D332-D338.
(8) Fairweather-Tait, S. J.; Collings, R.; Hurst, R. Selenium bioavailability: current knowledge and future research requirements. Am. I. Clin. Nutr. 2010, 91 (5), 1484S-1491S.

(9) Kryukov, G. V. Characterization of Mammalian Selenoproteomes. Science 2003, 300 (5624), 1439-1443.

(10) Fairweather-Tait, S. J.; Bao, Y.; Broadley, M. R.; Collings, R.; Ford, D.; Hesketh, J. E.; Hurst, R. Selenium in Human Health and Disease. Antioxid. Redox Signaling 2011, 14 (7), 1337-1383.

(11) Wen, H.; Carignan, J. Reviews on atmospheric selenium: Emissions, speciation and fate. Atmos. Environ. 2007, 41 (34), 71517165.

(12) Gilfedder, B. S.; Lai, S. C.; Petri, M.; Biester, H.; Hoffmann, T. Iodine speciation in rain, snow and aerosols. Atmos. Chem. Phys. 2008, 8 (20), 6069-6084.

(13) Låg, J.; Steiness, E. Soil selenium in relation to precipitation. AMBIO A Journal of the Human Environment 1974, 3 (6), 237-238.

(14) Lee, K.; Hong, S.-B.; Lee, J.; Chung, J.; Hur, S.-D.; Hong, S. Seasonal variation in the input of atmospheric selenium to northwestern Greenland snow. Sci. Total Environ. 2015, 526, 49-57.

(15) Wen, H.; Carignan, J. Ocean to continent transfer of atmospheric Se as revealed by epiphytic lichens. Environ. Pollut. 2009, 157 (10), 2790-2797.

(16) Butler, J. H.; King, D. B.; Lobert, J. M.; Montzka, S. A.; YvonLewis, S. A.; Hall, B. D.; Warwick, N. J.; Mondeel, D. J.; Aydin, M.; Elkins, J. W. Oceanic distributions and emissions of short-lived halocarbons. Global Biogeochem. Cv. 2007, 21 (1), GB1023.

(17) Saiz-Lopez, A.; Plane, J. M. C.; Baker, A. R.; Carpenter, L. J.; von Glasow, R.; Gómez Martín, J. C.; McFiggans, G.; Saunders, R. W. Atmospheric Chemistry of Iodine. Chem. Rev. 2012, 112 (3), 17731804.

(18) Carpenter, L. J.; MacDonald, S. M.; Shaw, M. D.; Kumar, R.; Saunders, R. W.; Parthipan, R.; Wilson, J.; Plane, J. M. C. Atmospheric iodine levels influenced by sea surface emissions of inorganic iodine. Nat. Geosci. 2013, 6 (2), 108-111.

(19) Bichsel, Y.; von Gunten, U. Oxidation of iodide and hypoiodous acid in the disinfection of natural waters. Environ. Sci. Technol. 1999, 33 (22), 4040-4045.

(20) Gilfedder, B. S.; Petri, M.; Biester, H. Iodine speciation in rain and snow: Implications for the atmospheric iodine sink. I. Geophvs. Res. 2007, 112, D07301.

(21) Weller, R.; Wöltjen, J.; Piel, C.; Resenberg, R.; Wagenbach, D.; König-Langlo, G.; Kriews, M. Seasonal variability of crustal and marine trace elements in the aerosol at Neumayer station, Antarctica. Tellus, Ser. B 2008, 60 (5), 742-752.

(22) Wang, L.; Tang, A. Oxidation mechanisms of dimethyl selenide and selenoxide in the atmosphere initiated by $\mathrm{OH}$ radical. A theoretical study. Chem. Phys. 2011, 382 (1-3), 98-103.

(23) Atkinson, R.; Aschmann, S. M.; Hasegawa, D.; ThompsonEagle, E. T.; Frankenberger, W. T. Kinetics of the atmospherically important reactions of dimethyl selenide. Environ. Sci. Technol. 1990, 24 (9), 1326-1332.

(24) Monahan-Pendergast, M.; Przybylek, M.; Lindblad, M.; Wilcox, J. Theoretical predictions of arsenic and selenium species under atmospheric conditions. Atmos. Environ. 2008, 42 (10), 2349-2357.

(25) Amouroux, D.; Donard, O. F. X. Evasion of selenium to the atmosphere via biomethylation processes in the Gironde estuary, France. Mar. Chem. 1997, 58 (1-2), 173-188.

(26) Amouroux, D.; Donard, O. F. X. Maritime emission of selenium to the atmosphere in Eastern Mediterranean seas. Geophys. Res. Lett. 1996, 23 (14), 1777-1780.

(27) Amouroux, D.; Liss, P. S.; Tessier, E.; Hamren-Larsson, M.; Donard, O. F. X. Role of oceans as biogenic sources of selenium. Earth Planet. Sci. Lett. 2001, 189 (3-4), 277-283.

(28) Tessier, E.; Amouroux, D.; Abril, G.; Lemaire, E.; Donard, O. F. $\mathrm{X}$. Formation and volatilisation of alkyl-iodides and -selenides in macrotidal estuaries. Biogeochemistry 2002, 59 (1), 183-206.

(29) Tessier, E.; Amouroux, D.; Donard, O. F. X. Biogenic Volatilization of Trace Elements from European Estuaries. In ACS Symposium Series; American Chemical Society: 2002; pp 151-165. 
(30) Redeker, K. R.; Wang, N.-Y.; Low, J. C.; McMillan, A.; Tyler, S. C.; Cicerone, R. J. Emissions of Methyl Halides and Methane from Rice Paddies. Science 2000, 290 (5493), 966-969.

(31) Lee-Taylor, J. Reevaluation of global emissions from rice paddies of methyl iodide and other species. Geophvs. Res. Lett. 2005, 32 (15), L15801.

(32) Matthews, E. Global Vegetation and Land Use: New HighResolution Data Bases for Climate Studies. I. Clim. Appl. Meteorol. 1983, 22 (3), 474-487.

(33) Dimmer, C. H.; Simmonds, P. G.; Nickless, G.; Bassford, M. R. Biogenic fluxes of halomethanes from Irish peatland ecosystems. Atmos. Environ. 2001, 35 (2), 321-330.

(34) Manley, S. L.; Wang, N.-Y.; Walser, M. L.; Cicerone, R. J. Coastal salt marshes as global methyl halide sources from determinations of intrinsic production by marsh plants. Global Biogeochem. Cv. 2006, 20 (3), GB3015.

(35) Vriens, B.; Lenz, M.; Charlet, L.; Berg, M.; Winkel, L. H. E. Natural wetland emissions of methylated trace elements. Nat. Commun. 2014, 5, 3035.

(36) Sive, B. C.; Varner, R. K.; Mao, H.; Blake, D. R.; Wingenter, O. W.; Talbot, R. A large terrestrial source of methyl iodide. Geophys. Res. Lett. 2007, 34, L17808.

(37) Gilfedder, B. S.; Petri, M.; Biester, H. Iodine and bromine speciation in snow and the effect of orographically induced precipitation. Atmos. Chem. Phvs. 2007, 7 (10), 2661-2669.

(38) Arimoto, R.; Duce, R. A.; Ray, B. J.; Hewitt, A. D.; Williams, J. Trace elements in the atmosphere of American Samoa: Concentrations and deposition to the tropical South Pacific. L. Geophvs. Res. 1987, 92 (D7), 8465.

(39) Arimoto, R.; Duce, R. A.; Ray, B. J.; Unni, C. K. Atmospheric trace elements at Enewetak Atoll: 2. Transport to the ocean by wet and dry deposition. I. Geophvs. Res. 1985, 90 (D1), 2391.

(40) Conde, J. E.; Sanz Alaejos, M. Selenium Concentrations in Natural and Environmental Waters. Chem. Rev. 1997, 97 (6), 19792004.

(41) Cutter, G. A.; Church, T. M. Selenium in western Atlantic precipitation. Nature 1986, 322 (6081), 720-722.

(42) De Gregori, I.; Lobos, M. a. G.; Pinochet, H. Selenium and its redox speciation in rainwater from sites of Valparaiso region in Chile, impacted by mining activities of copper ores. Water Res. 2002, 36 (1), $115-122$.

(43) Heaton, R. W.; Rahn, K. A.; Lowenthal, D. H. Determination of trace elements, including regional tracers, in Rhode Island precipitation. Atmos. Environ., Part A 1990, 24 (1), 147-153.

(44) Heaton, R. W.; Rahn, K. A.; Lowenthal, D. H. Regional apportionment of sulfate and tracer elements in Rhode Island precipitation. Atmos. Environ., Part A 1992, 26 (8), 1529-1543.

(45) Landing, W. M.; Caffrey, J. M.; Nolek, S. D.; Gosnell, K. J.; Parker, W. C. Atmospheric wet deposition of mercury and other trace elements in Pensacola, Florida. Atmos. Chem. Phys. 2010, 10 (10), 4867-4877.

(46) Piwonka, J.; Kaiser, G.; Tölg, G. Determination of selenium at $\mathrm{ng} / \mathrm{g}$ - and $\mathrm{pg} / \mathrm{g}$-levels by hydride generation-atomic absorption spectrometry in biotic materials. Fresenius' $Z$. Anal. Chem. 1985, 321 (3), 225-234.

(47) Robberecht, H.; Van Grieken, R.; Van Sprundel, M.; Vanden Berghe, D.; Deelstra, H. Selenium in environmental and drinking waters of Belgium. Sci. Total Environ. 1983, 26 (2), 163-172.

(48) Shi, G.; Teng, J.; Ma, H.; Li, Y.; Sun, B. Metals and metalloids in precipitation collected during CHINARE campaign from Shanghai, China, to Zhongshan Station, Antarctica: Spatial variability and source identification. Global Biogeochemical Cycles 2015, 29 (6), 760-774.

(49) Suzuki, Y.; Sugimura, Y.; Miyake, Y. The Content of Selenium and Its Chemical Form in Rain Water and Aerosol in Tokyo. I. Meteorol. Soc. Ipn. 1981, 59 (3), 405-409.

(50) Wang, D.; Alfthan, G.; Aro, A. Determination of total selenium and dissolved selenium species in natural waters by fluorometry. Environ. Sci. Technol. 1994, 28 (3), 383-387.
(51) Winkel, L. H. E.; Vriens, B.; Jones, G. D.; Schneider, L. S.; Pilon-Smits, E.; Bañuelos, G. S. Selenium Cycling Across Soil-PlantAtmosphere Interfaces: A Critical Review. Nutrients 2015, 7 (6), 4199-4239.

(52) Blazina, T.; Laederach, A.; Jones, G. D.; Sodemann, H.; Wernli, H.; Kirchner, J.; Winkel, L. H. E. Marine Primary Productivity as a Potential Indirect Source of Selenium and Other Trace Elements in Atmospheric Deposition. Environ. Sci. Technol. 2017, 51 (1), 108118

(53) Papoff, P.; Bocci, F.; Lanza, F. Speciation of Selenium in Natural Waters and Snow by DPCSV at the Hanging Mercury Drop Electrode. Microchem. I. 1998, 59 (1), 50-76.

(54) Wallschläger, D.; London, J. Determination of inorganic selenium species in rain and sea waters by anion exchange chromatography-hydride generation-inductively-coupled plasma-dynamic reaction cell-mass spectrometry (AEC-HG-ICP-DRC-MS). I. Anal. At. Spectrom. 2004, 19 (9), 1119-1127.

(55) Ross, H. Atmospheric Selenium. Report CM-66 1984; Department of Meteorology, University of Stockholm: Stockholm, ISSN 0280-445X, 69.

(56) Ranville, M. A.; Cutter, G. A.; Buck, C. S.; Landing, W. M.; Cutter, L. S.; Resing, J. A.; Flegal, A. R. Aeolian Contamination of Se and $\mathrm{Ag}$ in the North Pacific from Asian Fossil Fuel Combustion. Environ. Sci. Technol. 2010, 44 (5), 1587-1593.

(57) Steinnes, E. Soils and geomedicine. Environ. Geochem. Health 2009, 31 (5), 523-535.

(58) Fuge, R. Sources of halogens in the environment, influences on human and animal health. Environ. Geochem. Health 1988, 10 (2), $51-61$.

(59) Fuge, R.; Johnson, C. C. The geochemistry of iodine - a review. Environ. Geochem. Health 1986, 8 (2), 31-54.

(60) Carpenter, L. J.; Archer, S. D.; Beale, R. Ocean-atmosphere trace gas exchange. Chem. Soc. Rev. 2012, 41 (19), 6473.

(61) Salawitch, R. J. Atmospheric chemistry: Biogenic bromine. Nature 2006, 439 (7074), 275-277.

(62) Parrella, J. P.; Jacob, D. J.; Liang, Q.; Zhang, Y.; Mickley, L. J.; Miller, B.; Evans, M. J.; Yang, X.; Pyle, J. A.; Theys, N.; Van Roozendael, M. Tropospheric bromine chemistry: implications for present and pre-industrial ozone and mercury. Atmos. Chem. Phvs. 2012, 12 (15), 6723-6740.

(63) von Glasow, R.; Crutzen, P. J. Model study of multiphase DMS oxidation with a focus on halogens. Atmos. Chem. Phys. 2004, 4 (3), 589-608.

(64) Hoffmann, E. H.; Tilgner, A.; Schrödner, R.; Bräuer, P.; Wolke, R.; Herrmann, H. An advanced modeling study on the impacts and atmospheric implications of multiphase dimethyl sulfide chemistry. Proc. Natl. Acad. Sci. U. S. A. 2016, 113 (42), 11776-11781.

(65) Hoyle, C. R.; et al. Aqueous phase oxidation of sulphur dioxide by ozone in cloud droplets. Atmos. Chem. Phvs. 2016, 16 (3), 16931712.

(66) Frege, C.; et al. J. Chemical characterization of atmospheric ions at the high altitude research station Jungfraujoch (Switzerland). Atmos. Chem. Phys. 2017, 17 (4), 2613-2629.

(67) Henne, S.; Brunner, D.; Folini, D.; Solberg, S.; Klausen, J.; Buchmann, B. Assessment of parameters describing representativeness of air quality in-situ measurement sites. Atmos. Chem. Phvs. 2010, 10 (8), 3561-3581.

(68) Dauthieu, M.; Bueno, M.; Darrouzes, J.; Gilon, N.; PotinGautier, M. Evaluation of porous graphitic carbon stationary phase for simultaneous preconcentration and separation of organic and inorganic selenium species in "clean" water systems. Iournal of Chromatography A 2006, 1114 (1), 34-39.

(69) Tolu, J.; Le Hécho, I.; Bueno, M.; Thiry, Y.; Potin-Gautier, M. Selenium speciation analysis at trace level in soils. Anal. Chim. Acta 2011, 684 (1-2), 126-133.

(70) Bueno, M.; Darrouzes, J. Determination of Organic and Inorganic Selenium Species Using HPLC-ICP-MS. Agilent Application Note, Agilent Technologies, US, 2007, 5. 
(71) European Committee for Standardization, EUROPEAN STANDARD EN 1484, ICS 13.060.30, Water analysis: Guidelines for the determination of total organic carbon (TOC) and dissolved organic carbon (DOC); CEN, Central Secretariat: Brussels, 1997, 13 pp.

(72) Lang, S. Q.; Bernasconi, S. M.; Früh-Green, G. L. Stable isotope analysis of organic carbon in small $(\mu \mathrm{g} \mathrm{C})$ samples and dissolved organic matter using a GasBench preparation device. Rapid Commun. Mass Spectrom. 2012, 26 (1), 9-16.

(73) Lang, S. Q.; Früh-Green, G. L.; Bernasconi, S. M.; Wacker, L. Isotopic $\left(\delta^{13} \mathrm{C}, \Delta^{14} \mathrm{C}\right)$ analysis of organic acids in marine samples using wet chemical oxidation. Limnol. Oceanogr.: Methods 2013, 11 (4), 161-175.

(74) Lang, S. Q.; Lilley, M. D.; Hedges, J. I. A method to measure the isotopic (13C) composition of dissolved organic carbon using a high temperature combustion instrument. Mar. Chem. 2007, 103 (34), 318-326.

(75) Sprenger, M.; Wernli, H. The LAGRANTO Lagrangian analysis tool - version 2.0. Geosci. Model Dev. 2015, 8 (8), 2569-2586.

(76) Wernli, H.; Davies, H. C. A Lagrangian-based analysis of extratropical cyclones. I: The method and some applications. $\underline{\text { Q. I. R }}$ Meteorol. Soc. 1997, 123, 467-489.

(77) Dee, D. P.; et al. The ERA-Interim reanalysis: configuration and performance of the data assimilation system. Q. I. R. Meteorol. Soc. 2011, 137 (656), 553-597.

(78) Doms, G.; Schättler, U. A description of the nonhydrostatic regional model LM, part I: dynamics and numerics; Deutscher Wetterdienst: Offenbach, Germany, 2002.

(79) Steppeler, J.; Doms, G.; Schattler, U.; Bitzer, H. W.; Gassmann, A.; Damrath, U.; Gregoric, G. Meso-gamma scale forecasts using the nonhydrostatic model LM. Meteorol. Atmos. Phys. 2003, 82 (1-4), 75-96.

(80) Sodemann, H.; Schwierz, C.; Wernli, H. Interannual variability of Greenland winter precipitation sources: Lagrangian moisture diagnostic and North Atlantic Oscillation influence. I. Geophvs. Res. 2008, 113, D03107.

(81) Gatz, D. F.; Nelson Dingle, A. Trace substances in rain water: concentration variations during convective rains, and their interpretation. Tellus 1971, 23 (1), 14-27.

(82) Baltensperger, U.; Gäggeler, H. W.; Jost, D. T.; Lugauer, M.; Schwikowski, M.; Weingartner, E.; Seibert, P. Aerosol climatology at the high-alpine site Jungfraujoch, Switzerland. I. Geophys. Res. Atmos. 1997, 102 (D16), 19707-19715.

(83) Collaud Coen, M.; Weingartner, E.; Furger, M.; Nyeki, S.; Prévôt, A. S. H.; Steinbacher, M.; Baltensperger, U. Aerosol climatology and planetary boundary influence at the Jungfraujoch analyzed by synoptic weather types. Atmos. Chem. Phvs. 2011, 11 (12), 5931-5944.

(84) Griffiths, A. D.; Conen, F.; Weingartner, E.; Zimmermann, L.; Chambers, S. D.; Williams, A. G.; Steinbacher, M. Surface-tomountaintop transport characterised by radon observations at the Jungfraujoch. Atmos. Chem. Phys. 2014, 14 (23), 12763-12779.

(85) Lugauer, M.; Baltensperger, U.; Furger, M.; Gäggeler, H. W.; Jost, D. T.; Nyeki, S.; Schwikowski, M. Influences of vertical transport and scavenging on aerosol particle surface area and radon decay product concentrations at the Jungfraujoch ( $3454 \mathrm{~m}$ above sea level). Iournal of Geophysical Research: Atmospheres 2000, 105 (D15), 19869-19879.

(86) Lugauer, M.; Baltensperger, U.; Furger, M.; Gäggeler, H. W.; Jost, D. T.; Schwikowski, M.; Wanner, H. Aerosol transport to the high Alpine sites Jungfraujoch (3454 m asl) and Colle Gnifetti (4452 m asl). Tellus, Ser. B 1998, 50 (1), 76-92.

(87) Nyeki, S.; Baltensperger, U.; Colbeck, I.; Jost, D. T.; Weingartner, E.; Gäggeler, H. W. The Jungfraujoch high-alpine research station $(3454 \mathrm{~m})$ as a background clean continental site for the measurement of aerosol parameters. L. Geophys. Res. Atmos. 1998, 103 (D6), 6097-6107.

(88) Aemisegger, F.; Pfahl, S.; Sodemann, H.; Lehner, I.; Seneviratne, S. I.; Wernli, H. Deuterium excess as a proxy for continental moisture recycling and plant transpiration. Atmos. Chem. Phvs. 2014, 14 (8), 4029-4054.

(89) Sodemann, H.; Zubler, E. Seasonal and inter-annual variability of the moisture sources for Alpine precipitation during 1995-2002. Int. J. Climatol. 2010, 30, 947-961.

(90) Avery, G., Jr.; Willey, J.; Kieber, R. Carbon isotopic characterization of dissolved organic carbon in rainwater: Terrestrial and marine influences. Atmos. Environ. 2006, 40 (39), 7539-7545.

(91) Avery, G. B.; Biswas, K. F.; Mead, R.; Southwell, M.; Willey, J. D.; Kieber, R. J.; Mullaugh, K. M. Carbon isotopic characterization of hydrophobic dissolved organic carbon in rainwater. Atmos. Environ. 2013, 68, 230-234.

(92) Willey, J. D.; Kieber, R. J.; Eyman, M. S.; Avery, G. B. Rainwater dissolved organic carbon: Concentrations and global flux. Global Biogeochem. Cv. 2000, 14 (1), 139-148.

(93) Raymond, P. A. The composition and transport of organic carbon in rainfall: Insights from the natural (13C and14C) isotopes of carbon. Geophvs. Res. Lett. 2005, 32 (14), L14402.

(94) Wang, X.; Ge, T.; Xu, C.; Xue, Y.; Luo, C. Carbon isotopic (14C and 13C) characterization of fossil-fuel derived dissolved organic carbon in wet precipitation in Shandong Province, China. I. Atmos. Chem. 2016, 73 (2), 207-221.

(95) Sturm, P.; Leuenberger, M.; Schmidt, M. Atmospheric O2, $\mathrm{CO} 2$ and $\delta 13 \mathrm{C}$ observations from the remote sites Jungfraujoch, Switzerland, and Puy de Dôme, France. Geophys. Res. Lett. 2005, 32 (17), L17811.

(96) Tuzson, B.; Henne, S.; Brunner, D.; Steinbacher, M.; Mohn, J.; Buchmann, B.; Emmenegger, L. Continuous isotopic composition measurements of tropospheric $\mathrm{CO}_{2}$ at Jungfraujoch (3580 m a.s.l.), Switzerland: real-time observation of regional pollution events. Atmos. Chem. Phys. 2011, 11 (4), 1685-1696.

(97) Levin, I.; et al. Three years of trace gas observations over the EuroSiberian domain derived from aircraft sampling - a concerted action. Tellus, Ser. B 2002, 54 (5), 696-712.

(98) Pang, J.; Wen, X.; Sun, X. Mixing ratio and carbon isotopic composition investigation of atmospheric $\mathrm{CO} 2$ in Beijing, China. Sci. Total Environ. 2016, 539, 322-330.

(99) Fröhlich, R.; et al. Fourteen months of on-line measurements of the non-refractory submicron aerosol at the Jungfraujoch $(3580 \mathrm{~m}$ a.s.l.) - chemical composition, origins and organic aerosol sources. Atmos. Chem. Phvs. 2015, 15, 11373-11398.

(100) Ceburnis, D. G.; et al. Quantification of the carbonaceous matter origin in submicron marine aerosol by $13 \mathrm{C}$ and $14 \mathrm{C}$ isotope analysis. Atmos. Chem. Phvs. 2011, 11 (16), 8593-8606.

(101) Gromov, S.; Brenninkmeijer, C. A. M.; Jöckel, P. Proxies and uncertainties for $13 \mathrm{C} / 12 \mathrm{C}$ ratios of atmospheric reactive gases emissions. Atmos. Chem. Phvs. Discuss. 2017, 1-41.

(102) Stein, O.; Rudolph, J. Modeling and interpretation of stable carbon isotope ratios of ethane in global chemical transport models. $[$. Geophys. Res. 2007, 112, D14308.

(103) Galí, M.; Simó, R. A meta-analysis of oceanic DMS and DMSP cycling processes: Disentangling the summer paradox. Global Biogeochem. Cv. 2015, 29 (4), 496-515.

(104) Simó, R.; Pedrós-Alió, C. Role of vertical mixing in controlling the oceanic production of dimethyl sulphide. Nature 1999, 402 (6760), 396-399.

(105) Berresheim, H.; Andreae, M. O.; Iverson, R. L.; Li, S. M. Seasonal variations of dimethylsulfide emissions and atmospheric sulfur and nitrogen species over the western north Atlantic Ocean. Tellus, Ser. B 1991, 43 (5), 353-372.

(106) Campos, M. L. A. M.; Nightingale, P. D.; Jickells, T. D. A comparison of methyl iodide emissions from seawater and wet depositional fluxes of iodine over the southern North Sea. Tellus, Ser. B 1996, 48 (1), 106-114.

(107) Criquet, J.; Allard, S.; Salhi, E.; Joll, C. A.; Heitz, A.; von Gunten, U. Iodate and Iodo-Trihalomethane Formation during Chlorination of Iodide-Containing Waters: Role of Bromide. Environ. Sci. Technol. 2012, 46 (13), 7350-7357. 
(108) Baker, A. R. Marine aerosol iodine chemistry: The importance of soluble organic iodine. Environ. Chem. 2005, 2 (4), 295-298.

(109) Pechtl, S.; Schmitz, G.; von Glasow, R. Modelling iodideiodate speciation in atmospheric aerosol: Contributions of inorganic and organic iodine chemistry. Atmos. Chem. Phys. 2007, 7, 13811393.

(110) Neal, C.; Neal, M.; Hughes, S.; Wickham, H.; Hill, L.; Harman, S. Bromine and bromide in rainfall, cloud, stream and groundwater in the Plynlimon area of mid-Wales. Hvdrol. Earth Syst. Sci. 2007, 11 (1), 301-312.

(111) Sander, R.; et al. Inorganic bromine in the marine boundary layer: a critical review. Atmos. Chem. Phys. 2003, 3, 1301-1336.

(112) Butler, J. H. Atmospheric chemistry: Better budgets for methyl halides? Nature 2000, 403 (6767), 260-261.

(113) Horst, A.; Holmstrand, H.; Andersson, P.; Thornton, B. F.; Wishkerman, A.; Keppler, F.; Gustafsson, O. Stable bromine isotopic composition of methyl bromide released from plant matter. Geochim. Cosmochim. Acta 2014, 125, 186-195.

(114) Wishkerman, A.; Gebhardt, S.; McRoberts, C. W.; Hamilton, J. T. G.; Williams, J.; Keppler, F. Abiotic methyl bromide formation from vegetation, and its strong dependence on temperature. Environ. Sci. Technol. 2008, 42 (18), 6837-6842. 